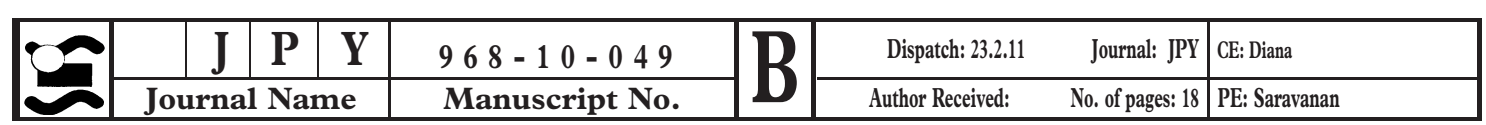

J. Phycol. 47, ***_**** (2011)

(C) 2011 Phycological Society of America

DOI: $10.1111 /$ j.1529-8817.2011.00968.x

\title{
BARRUFETA BRAVENSIS GEN. NOV. SP. NOV. (DINOPHYCEAE): A NEW BLOOM-FORMING SPECIES FROM THE NW MEDITERRANEAN SEA ${ }^{1}$
}

\author{
Nagore Sampedro ${ }^{2}$ \\ Institut de Ciències del Mar, CSIC, Pg. Marítim de la Barceloneta, 37-49, 08003 Barcelona, Spain \\ Santiago Fraga \\ Centro Oceanográfico de Vigo (IEO) Subida a Radio Faro 50, 36390 Vigo, Spain \\ Antonella Penna, Silvia Casabianca, \\ Dep. of Biomolecular Sciences, University of Urbino, 61100 Pesaro, Italy \\ Manuel Zapata \\ Instituto de Investigaciones Marinas, CSIC, Av. Eduardo Cabello 6, 36208 Vigo, Spain \\ Claudio Fuentes Grünewald \\ Institut de Ciències del Mar, CSIC, Pg. Marítim de la Barceloneta, 37-49, 08003 Barcelona, Spain \\ Institut de Ciència i Tecnologia Ambientals, Universitat Autònoma de Barcelona, 08193 Bellaterra, Barcelona, Spain
}

Pilar Riobó

Instituto de Investigaciones Marinas, CSIC, Av. Eduardo Cabello 6, 36208 Vigo, Spain

and Jordi Camp

Institut de Ciències del Mar, CSIC, Pg. Marítim de la Barceloneta, 37-49, 08003 Barcelona, Spain

The present study describes a new dinoflagellate genus, Barrufeta Sampedro et S. Fraga gen. nov., with one new species, B. bravensis Sampedro et S. Fraga sp. nov., isolated from the Costa Brava (NW Mediterranean Sea). The dinoflagellate was characterized at the genus and species levels by LM and EM; LSU and internal transcribed spacer (ITS) rDNA sequences; and HPLC analyses of the pigments, fatty acids, and possible presence of toxins of several cultured strains. The new Barrufeta species is oval shaped (22$35 \mu \mathrm{m}$ long and 16-25 $\mu \mathrm{m}$ wide) and dorsoventrally flattened. It possesses numerous small chloroplasts that radiate from two large, equatorially located pyrenoids and is a typical peridinin-containing dinoflagellate. The nucleus is in the anterior part of the epicone. The apical groove has a characteristic "Smurf-cap" shape that runs counterclockwise on the epicone and terminates on its right posterior part. $B$. bravensis is similar to the previously described species Gyrodinium resplendens Hulburt in its external morphology but the original report of the latter lacked a description of the complete shape of the apical groove. It is therefore likely that some of the $G$. resplendens species reported in the literature are Barrufeta since they possess a Barrufeta-type apical groove. Fatty acids of Barrufeta were more similar to

\footnotetext{
${ }^{1}$ Received 26 February 2010. Accepted 06 August 2010.

${ }^{2}$ Author for correspondence: e-mail nagore@icm.csic.es.
}

those of Karenia brevis than those obtained from other unarmored analyzed species including three species of Gymnodinium and Akashiwo sanguinea.

Key index words: Barrufeta bravensis; dinoflagellates; Gymnodinium; Gyrodinium; molecular phylogeny; ultrastructure

Abbreviations: av, amphiesmal vesicles; CCVIEO, Culture collection of Microalgae of the Centro Oceanográfico de Vigo; ch, chloroplasts; cr, chromosomes; CTP, cytidine triphosphate; DAPI, 4',6-diamidino-2-phenylindole; DIC, differential interference contrast microscopy; g, golgi; GC, gas chromatography; ITS, internal transcribed spacer; l, lipid droplet; If, longitudinal flagella; $m$, mucocyst-like vesicles; MgDVP, Mg-2,4-divinyl pheporphyrin; ML, maximum likelihood; MP, maximum parsimony; MUFA, monounsaturated fatty acid; $\mathbf{n}$, nucleus; NFC, nuclear fibrous connective; NJ, neighbor joining; nu, nucleolus; pu, pusule; PUFA, polyunsaturated fatty acid; py, pyrenoid; s, starch grain; SFA, saturated fatty acid; t, trichocysts; TTP, thymidine triphosphate; $v$, vacuoles

Unarmored dinoflagellates have always been difficult to classify. Indeed, early species descriptions were based only on basic morphological characteristics 
visible by LM, such as cell shape and size; girdle displacement; number, position, and color of the chromatophores; position of the nucleus; and the nature of the cell surface (smooth or striated). One of the problems with these first descriptions was that in some cases, they referred to fixed samples or to organisms in poor condition and thus in neither case representative of living cells. Inaccurate descriptions can also result from the extreme sensitivity of the living organisms to confinement between the slide and the coverglass and from observation only of nonmoving cells. Furthermore, the taxonomic criteria previously used to distinguish between two genera of unarmored dinoflagellates were frequently not reliable. Since these criteria were drawn from continuous characteristics (e.g., the degree of cingular displacement; Kofoid and Swezy 1921), such as used to distinguish the genera Gymnodinium and Gyrodinium, the cutoff that determined one genus versus the other could not be precisely defined, with particular difficulty arising in many borderline cases.

The taxonomy of unarmored dinoflagellates progressed following the information obtained from ultrastructural studies (Dodge 1974, Steidinger et al. 1978) as well as from analyses of pigment composition (Jeffrey et al. 1975 and references therein, Bjørnland and Tangen 1979) and the morphology of the dinoflagellate apical groove (Takayama 1981, 1985, Takayama and Adachi 1984). More recently, the morphological and ultrastructural investigations have been combined with phylogenetic determinations (Saunders et al. 1997, Hansen et al. 2000a), which, in turn, provide a new focus to the classification of genera comprising the unarmored dinoflagellates. Daugbjerg et al. (2000) used this approach to redescribe the most important genera of unarmored dinoflagellates (Gymnodinium and Gyrodini$u m$ ), in addition to describing three new genera and proposing a total of 17 new genus-species combinations. The features of the new genera were based on the phylogenetic analysis, specifically, of the LSU of rDNA, in combination with morphological evaluation of the apical groove, several ultrastructural details (e.g., the presence or absence of nuclear chambers in the nuclear envelope), and the identities of the major accessory pigments. Since the shape of the apical groove was determined to differ in each genus, it provided a reliable generic characteristic, one that was usually observable by SEM. This new classification of unarmored dinoflagellates likewise yielded new genus-species combinations in addition to a new genus, Takayama (de Salas et al. 2003, Murray et al. 2007). However, Daugbjerg et al. (2000) also made a few exceptions: for example, the apical groove of Lepidodinium viride $\mathrm{M}$. Watanabe, S. Suda, I. Inouye, Sawaguchi et Chihara is similar to that of Gymnodinium, and the analysis of SSU rDNA sequences places this species within or close to Gymnodinium sensu stricto (Saunders et al. 1997); nonetheless, the Lepidodinium genus was retained based on the presence of both an outer layer of body scales and pigments of Chlorophyta origin (Watanabe et al. 1990). Hansen et al. (2007) compared L. viride with Gymnodinium chlorophorum Elbr. et Schnepf. Although the latter species lacks body scales, similarities between the two species at the ultrastructural, pigment, and genetic levels led the authors to propose the new combination L. chlorophorum (Elbr. et Schnepf) Gert Hansen, Botes et de Salas. The use of fatty acids as a chemotaxonomic tool in marine microalgae has been suggested by some authors. Fatty acids of unarmored dinoflagellates have also been studied in this way. Mooney et al. (2007), for example, examined eight species of marine gymnodinioids and proposed the ratio of 28:7n6/28:8n 3 as a chemotaxonomic marker at the species level. There are, to the authors' knowledge, no studies on chemotaxonomic tools based on fatty acids to distinguish between unarmored genera.

Since 1982, blooms of Alexandrium taylori Balech causing intensely brown/green-colored waters have been observed along some of the beaches of the Costa Brava (NW Mediterranean Sea) in the summer months (from June to September), when the influx of tourists is the greatest (Garcés et al. 1999). Since 1995, routine monitoring of harmful algal blooms (HABs) at La Fosca beach has led to the additional detection of an unarmored dinoflagellate during the same period that the A. taylori bloom occurs, but the preservation of this gymnodinioid species with Lugol's solution prevented its identification. Therefore, to properly identify this species, several strains from the blooms that occurred in 2002 and 2005 were isolated. Our efforts led to the identification of $B$. bravensis gen. et sp. nov, described herein, which was based on LM and SEM examinations of its external morphology; phylogenetic analysis of its LSU and ITS rDNA; and analyses of its ultrastructure, pigments, and fatty acids composition.

\section{MATERIALS AND METHODS}

Strain isolation and cultures. Strains isolated from La Fosca beach, Costa Brava, during September 2002 and August 2005 were grown in L1 medium without silicate (Guillard and Hargraves 1993) and prepared with coastal seawater. The cultures were incubated at $20^{\circ} \mathrm{C}$ with a 12:12 light: dark (L:D) photoperiod and an irradiance of $\sim 100 \mu \mathrm{mol}$ photons $\cdot \mathrm{m}^{-2} \cdot \mathrm{s}^{-1}$. The salinity was adjusted to 32 (psu) for LM and analyses of pigment, fatty acid, and toxin content and 37.8 (psu) for SEM and TEM. The culture used for TEM analysis, belonging to the strain VGO864, was accompanied by a small, unknown photosynthetic oval, almost spherical, stramenopile measuring $\sim 3 \mu \mathrm{m}$ long and $\sim 2.5 \mu \mathrm{m}$ wide. The cultures were deposited at the Culture Collection of Microalgae of the Centro Oceanográfico de Vigo (CCVIEO; Vigo, Spain) and in the Provasoli-Guillard National Center for Culture of Marine Phytoplankton (CCMP; West Boothbay Harbor, ME, USA). Other unarmored dinoflagellates (Akashiwo sanguinea (Hirasaka) Gert Hansen et Moestrup 2000 (VGO626), Gymnodinium microreticulatum Bolch (VGO328), Gymnodinium catenatum L. E. Graham (Est14H5), Gymnodinium impudicum (S. Fraga et I. 
Bravo) Gert Hansen et Moestrup (VGO665), and Karenia brevis (C. C. Davis) Gert Hansen et Moestrup (CCMP2281) were cultivated under the same conditions to allow comparison of their fatty acid contents with those of B. bravensis (VGO864).

LM. Live cells were examined and photographed under bright-field and epifluorescence (lamp $50 \mathrm{~W}$ ) microscopy using a Leica DM IRB (Leica Microsystems GmbH, Wetzlar, Germany) inverted microscope connected to a ProgRes C10 (JENOPTIK Laser, Optik, Systeme GmbH, Jena, Germany) digital camera. Nuclei were stained with 4',6-diamidino-21 phenylindole ${ }_{\Delta}(\mathrm{DAPI})$ (Sigma-Aldrich, St. Louis, MO, USA) at a final concentration of $2 \mu \mathrm{g} \cdot \mathrm{mL}^{-1}$. A stained nucleus was photographed through a UV filter, and immediately afterward, another image was taken with a blue filter in order to capture the chloroplast's autofluorescence in the same cell. The two images were overlapped using Adobe Photoshop (Adobe Systems Inc., San Jose, CA, USA). Cellular dimensions and the degree of girdle displacement were determined in 50 cells

2 using ProgRes capturePro v 2.1 şofware. Nomarski microphotographs were taken with a Canon EOS D60 (Canon Inc., Tokyo, Japan) digital camera connected to a Leica DMLA light microscope (Leica Microsystems GmbH).

SEM. Cells of B. bravensis were fixed for $15 \mathrm{~min}$ at room temperature with an adequate volume of osmium tetroxide $4 \%$ (dissolved in seawater) to reach a final concentration of $1 \%$; $\mathrm{pH}$ was not adjusted. The cells fixed were then filtered through a $13 \mathrm{~mm}$ diameter Nucleopore (Pleasanton, CA, USA) polycarbonate filter with a pore size of 2 or $5 \mu \mathrm{m}$. The filtered cells were then washed in distilled water; dehydrated in $25,50,75$, 95, and $100 \%$ ethanol, $10 \mathrm{~min}$ each; and critical-point-dried. The filters were mounted on stubs, sputter-coated with gold, and examined with a JEOL JSM-6500F scanning electron microscope (JEOL-USA Inc., Peabody, MA, USA). To compare the structure of the apical groove of B. bravensis with the same structure in a related species of Gymnodinium, two SEM preparations used 17 years ago for the description of the G. impudicum (see Fraga et al. 1995 for more information on the methodology of SEM) were reexamined using a variablepressure scanning electron microscope Hitachi S-3500N (Hitachi High Technologies Corp., Japan).

TEM. B. bravensis VGO864 was fixed in an equal volume of a mixture of $4 \%$ glutaraldehyde and $0.4 \%$ osmium tetroxide (previously dissolved in distilled water to $4 \%$ concentration, and from $4 \%$ to $0.4 \%$ in culture medium) for $30 \mathrm{~min}$ at $4^{\circ} \mathrm{C}$, pelleted by centrifugation, washed in culture medium, and finally covered in $2.5 \%$ warm agar. After the agar had cooled and solidified, it was peeled off the filter (Hernández 1992), divided into smaller pieces, and postfixed for $1 \mathrm{~h}$ in $0.8 \%$ FeCNK and $1 \%$ osmium tetroxide prepared in $0.1 \mathrm{M} \mathrm{Na}$ cacodylate buffer ( $\mathrm{pH}$ 7.4). After washing in buffer the material was dehydrated in an acetone series $(50,70,80$, $2 \times 90,3 \times 96,3 \times 100 \%)$, embedded in Spurr's resin, and then sectioned on an Reichert Jung Ultracut E (Capovani Brothers Inc., Scotia, NY, USA) ultramicrotome using a diamond knife (Diatome, Hatfield, PA, USA). The sections were collected on a 200-mesh grid and placed on a Formvar film and then stained in $2 \%$ uranyl acetate and lead citrate following the method of Reynolds (1963). Sections were examined in a JEOL JEM-1010 electron microscope (JEOLUSA Inc.) operated at $80 \mathrm{kV}$. Micrographs were taken using a Gatan, BioScan model 792 (Gatan Inc., Pleasanton, CA, USA) digital camera.

Pigment analyses. Sample preparation: Prior to HPLC pigment analysis, the health and characteristic morphology of the cells were confirmed by LM. Three hours into the light cycle, cells from cultures in the exponential phase of growth were harvested, and a $14 \mathrm{~mL}$ aliquot of the culture was filtered onto Whatman GF/F filters (Whatman plc, Maidstone, Kent, UK) under reduced pressure. The filters were frozen immediately at $-25^{\circ} \mathrm{C}$ and analyzed within $12 \mathrm{~h}$.

Pigment extraction: The frozen filters were placed in Teflonlined screw-capped tubes and the pigments were subsequently extracted with $5 \mathrm{~mL}$ of $90 \%$ acetone, using a stainless steel spatula to grind the filter. The tubes were chilled in a beaker of ice and the contents sonicated for $5 \mathrm{~min}$ in an ultrasonic bath. The extracts were then filtered through syringe filters (MFS HP020, $25 \mathrm{~mm}, 0.20 \mu \mathrm{m}$ pore size, hydrophilic PTFE, Advantec, MFS Inc. Dublin, CA, USA) to remove cell and filter debris. An aliquot $(0.5 \mathrm{~mL})$ of acetone extract was mixed with $0.2 \mathrm{~mL}$ of water, followed by immediate injection of a $200 \mu \mathrm{L}$ sample into the HPLC column. This procedure avoids distortion of the early eluting peaks (Zapata and Garrido 1991) and prevents the loss of nonpolar pigments prior to column injection.

HPLC analysis. Pigments were separated by HPLC in a system consisting of a Waters (Waters Corporation, Milford, MA, USA) Alliance 2695 separation module and a Waters 996 diode-array detector (1.2 $\mathrm{nm}$ optical resolution) interfaced with a Waters 474 scanning fluorescence detector by means of a Sat/In analog interface. The chromatographic system was controlled using Millenium 32 software (Waters). Pigments were separated according to the HPLC method of Zapata et al. (2000), with a reformulated mobile phase A and using a $\mathrm{C}_{8}$ monomeric Waters Symmetry column $(150 \times 4.6 \mathrm{~mm}, 3.5 \mu \mathrm{m}$ particle size, $10 \mathrm{~nm}$ pore size). Eluent A consisted of methanol:acetonitrile :0.025 M aqueous pyridine (50:25:25 v/v/v), and eluent $B$ of methanol:acetonitrile:acetone $(20: 60: 20 \mathrm{v} / \mathrm{v} / \mathrm{v})$. The elution gradient was as follows (time, $\% \mathrm{~B}): \mathrm{t}_{0}, 0 \% ; \mathrm{t}_{22}, 40 \% ; \mathrm{t}_{28}, 95 \% ; \mathrm{t}_{37}, 95 \% ; \mathrm{t}_{40}, 0 \%$. The flow rate was $1.0 \mathrm{~mL} \cdot \mathrm{min}^{-1}$, and the column temperature was $25^{\circ} \mathrm{C}$. Solvents were HPLC grade (Romil-SpS $S^{\mathrm{TM}}$ Ltd., The Source Convent Waterbeach, Cambridge, UK); pyridine was reagent grade (Merck, Darmstadt, Germany).

Pigments were identified either by cochromatography with authentic standards obtained from SCOR reference cultures or by diode-array spectroscopy (see Zapata et al. 2000). The purity of the peaks was confirmed, and the spectral information then compared with a library of chl and carotenoid spectra of pigments extracted from standard phytoplankton cultures (Zapata et al. 2000) or supplied by DHI (DHI Laboratory Products, Hørsholm, Denmark). The molar extinction coefficients $\left(\varepsilon ; 1 \cdot \mathrm{mol}^{-1} \cdot \mathrm{cm}^{-1}\right)$ provided by Jeffrey $(1997)$ were used for pigment quantification.

Toxin analyses. Samples of B. bravensis cultures were filtered onto $47 \mathrm{~mm}$ glass fiber filters (Whatman GF/C). One of the filters was transferred to a $15 \mathrm{~mL}$ centrifuge tube containing PBS (Emura et al. 2004) for protein extraction. The other filters were treated with $0.1 \mathrm{M} \mathrm{HCl}$ to extract dinoflagellate toxins. These acidic extracts were used for the mouse bioassay (MBA), chemical analyses, and the hemolytic assay; the PBS extract was used only for the hemolytic assay.

The presence or absence of hemolytic compounds in both the PBS and the acidic extracts was determined following the method published by Riobó et al. (2008) with slight modifications. This assay was carried out using sheep blood diluted in Alsever's solution, kindly provided by $\mathrm{Cz}$ Veterinaria, S.A. (Porriño, Pontevedra, Spain).

The presence or absence of paralytic shellfish poisoning (PSP) toxins in cultures was determined according to the Association of Official Analytical Chemist's (AOAC) MBA method (Association of Official Analytical Chemists (AQAC) 1990) and the HPLC method, the latter including po $\equiv \mathrm{mn}$ oxidation and fluorometric detection (Franco and Fernandez 1993).

Fatty acid analyses. Fatty acid analyses were carried out on the strain of B. bravensis (VGO864) and other strains of unarmored dinoflagellates (A. sanguinea [VGO626], G. microreticulatum [VGO328], G. catenatum [Est14H5], G. impudicum 
[VGO665], and K. brevis [CCMP2281]). Duplicate or triplicate $(500 \mathrm{~mL})$ exponentially growing cultures were filtered through Whatman GF/F $(25 \mathrm{~mm})$ precombusted glass-fiber filters, immediately frozen in liquid $\mathrm{N}_{2}$, freeze-dried for $12 \mathrm{~h}$, and stored at $-20^{\circ} \mathrm{C}$ until analysis. Cellular lipids were extracted with 3:1 DCM:MeOH (dichloromethane:methanol), according to the method of Ruiz et al. (2004). The samples were redissolved in $0.5 \mathrm{~mL}$ of chloroform and eluted through a $500 \mathrm{mg}$ aminopropyl minicolumn (Waters Sep-Pak ${ }^{\circledR}$ Cartridges) previously activated with $4 \mathrm{~mL}$ of $n$-hexane according 4 to the method of Fuentes-Grunewald et al. (2009). The extracts were stored at $-20^{\circ} \mathrm{C}$ until gas chromatography (GC) analysis in a Thermo Finnigan Trace GC ultra instrument (Thermo Fisher Scientific Inc., Waltham, MA, USA) equipped with a flame ionization detector and splitless injector and fitted with a DB-5 Agilent column (30 m length, $0.25 \mathrm{~mm}$ internal diameter, and $0.25 \mu \mathrm{m}$ phase thickness) (Agilent Technologies Inc., Santa Clara, CA, USA). Helium was used as the carrier gas at a flow rate of $33 \mathrm{~cm} \cdot \mathrm{s}^{-1}$. The oven temperature was programmed to increase from $50^{\circ} \mathrm{C}$ to $320^{\circ} \mathrm{C}$ at $10^{\circ} \mathrm{C} \cdot \mathrm{min}^{-1}$. Injector and detector temperatures were $300^{\circ} \mathrm{C}$ and $320^{\circ} \mathrm{C}$, respectively. Fatty acid methyl esters (FAME) were identified by comparing their retention times to those of standard fatty acids (37 FAME compounds, Supelco® Mix C4-C24; Sigma-Aldrich, St. Louis, MO. USA). Fatty acids were quantified by integrating the areas under the peaks in the GC traces (Chromquest 4.1 software; Thermo Fisher Scientific Inc. Waltham, MA, USA), with calibrations derived from internal standards (2-octyldodecanoic acid and $5 \beta$-cholanic acid).

DNA extraction, PCR amplification, sequencing, and phylogenetic analyses. Cultures of $B$. bravensis were collected during the exponential growth phase by filtration on $3 \mu \mathrm{m}$ pore-size Isopore membrane filters (Millipore, Billerica, MA, USA). DNA was extracted and purified as described in Penna et al. (2005). Nuclear-encoded 5.8S rDNA and ITS regions were PCRamplified as described in Penna et al. (2008). The nuclearencoded LSU (D1/D2 regions) was amplified by using the primers D1R and D2C (Scholin and Anderson 1994) and the amplification protocol of Penna et al. (2008). Genomic DNA (1 ng) was amplified in a $50 \mu \mathrm{L}$ reaction mix containing $50 \mu \mathrm{M}$ each of dATP, dTTP, dCTP, and dGTP; $0.4 \mu \mathrm{M}$ of each primer; $4 \mathrm{mM} \mathrm{MgCl} 2 ; 1 \times$ reaction buffer (Diatheva, Fano, Italy); and 1.0 U Hot Rescue DNA Polymerase (Diatheva). Thermocycling was as follows: $10 \mathrm{~min}$ initial denaturation at $95^{\circ} \mathrm{C} ; 35$ cycles of $1 \mathrm{~min}$ at $95^{\circ} \mathrm{C}, 1 \mathrm{~min}$ at $50^{\circ} \mathrm{C}$, and $2.5 \mathrm{~min}$ at $72^{\circ} \mathrm{C}$; and a final elongation step of $7 \mathrm{~min}$ at $72^{\circ} \mathrm{C}$. Three PCR-amplified products corresponding to the $\mathrm{D} 1 / \mathrm{D} 2$ regions of the $\mathrm{LSU}$ gene and the 5.8S rDNA and ITS regions were pooled, purified, and then directly sequenced using the ABI PRISM 310 Genetic Analyzer (Perkin Elmer Corp., Applied Biosystems, Foster City, CA, USA) and the dye terminator method provided in the manufacturer's instructions (ABI PRISM Big Dye Terminator Cycle Sequencing Ready reaction Kit, Perkin Elmer Corp.). Sequences obtained from this study were aligned with those from GenBank using the CLUSTAL X2 program (Larkin et al. 2007) with default settings. Alignments were rechecked visually and edited manually; nonalignable regions were excluded prior to the phylogenetic analyses. The strains used in the molecular analyses are listed in Tables S1 and S2 (see the supplementary material), together with the GenBank accession numbers of their LSU and 5.8S-ITS rDNA sequences. Phylogenetic relationships, based on the D1/D2 LSU and 5.8S-ITS rDNA data, were inferred using the neighbor-joining (NJ), maximum-parsimony (MP), and maximum-likelihood (ML) methods. Sequences of Alexandrium affine $(\mathrm{H}$. Inoue et $\mathrm{Y}$. Fukuyo) Balech (AY294612) and Oxyrrhis marina Dujard. CCMP604 (AY566415) were used as outgroups in the LSU and ITS-5.8S rDNA phylogeny, respectively. The best-fit model of nucleotide substitution for the phylogenetic analyses was the
Akaike information criterion implemented in Modeltest 3.06 (Posada and Crandall 1998). For the LSU rDNA, the TVM+G model with gamma distribution for among-site variation was selected, with the alpha value of the gamma distribution equal to 0.497 . For the $5.8 \mathrm{~S}$ rDNA-ITS, the $\mathrm{TrN}+\mathrm{I}+\mathrm{G}$ model with gamma distribution for among-site variation was adopted, with alpha value of the gamma distribution equal to 0.924. This evolutionary model was used in the NJ distance matrix. MP analysis was performed using heuristic searches with treebisection-reconnection branch swapping. Branches were collapsed if their minimum length was 0 ; ambiguities and gaps were considered as missing data. The robustness of the NJ and MP trees was determined by bootstrapping with 1000 pseudoreplicates. Phylogenetic analyses were carried out using the software packages PAUP* ver. $4.0 \mathrm{~b} 10$ (Swofford 2002). ML analyses were run with RaxML (randomized axelerated maximum likelihood) software ver. 7.0.4 (Stamatakis et al. 2005), which adopts a general time reversible (GTR) substitution model and allows estimation of several parameters, such as the proportion of invariant sites and the alpha values of the gamma distribution for among-site rate variation. The LSU and 5.8-ITS rDNA sequences were subjected to ML analyses. Bootstrap values were calculated with 1,000 pseudoreplicates. Standard molecular indices were determined with Arlequin v. 3.0 (Excoffier et al. 2005).

\section{RESULTS}

Barrufeta Sampedro et S. gen. nov.

Dinoflagellati nudi cum peridinina ut principali pigmento lucis captore. Sulcus apicalis incipit in anteriore parte intersectionis surci et cinguli, currit diagonali modo in partem anteriorem ad dexteram, postea redit, sensu contrario motus horologii, in gyrum apicalis partis cellulae perlongum nodum transversalem componendum et finit prope dexteram partem ejus originis.

Unarmored dinoflagellates occur with peridinin as the major light-harvesting accessory pigment. An apical groove that starts in the anterior part of the intersection between the sulcus and the cingulum, runs diagonally to the anterior right side of the cell, and then turns counterclockwise around the apical part of the cell in a very elongated transversal loop before ending near the right side of its origin.

Etymology: Named after the shape of the epicone, which is due to the shape of the apical groove. It is similar to the cap of a "Smurf" (originally a "Schtroumpf'), a comic strip character invented by Peyo in 1958 and adapted later to television. In Catalan, barrufet means "Smurf," with barrufeta as the feminine form.

Type species: Barrufeta bravensis Sampedro et $\mathrm{S}$. Fraga sp. nov.

Barrufeta bravensis Sampedro et S. Fraga sp. nov.

Cellulae ovoideae dorsiventraliter complanatae, 22-35 $\mu \mathrm{m}$ longae 16-25 $\mathrm{m}$ latae. Et epiconus et hypoconus eamdem longuitudinem habent. Epiconus orbiculatus et frequenter cum parva protuberantia. Sulcus apicalis incipit in anteriore parte intersectionis surci et cinguli, currit diagonali modo in partem anteriorem ad dexteram, postea redit, 
sensu contrario motus horologii, in gyrum apicalis partis cellulae, perlongum nodum transversalem componendum et finit prope dexteram partem ejus originis. Hypoconus suaviter truncatus et leviter bilobulatus, extensionis sulci antapicem attingentis causa. Cingulum descendens 1.5-2 quantum habet latitudinis retractum. Permulti parvi cloroplasti pallidi obscuri, ex quibus multi exeunt e duobus magnis pyrenoidis sub cíngulo positis in utroque latere sulci. Peridinina ut principale pigmentum lucis captore. Nucleus plus minusve in centro epiconi locatus.

Cells oval in outline, dorsoventrally flattened, 22$35 \mu \mathrm{m}$ long and 16-25 $\mu \mathrm{m}$ wide. Epicone and hypocone are similar in length. Epicone is rounded and frequently found showing a slight protuberance. An apical groove that starts in the upper part of the intersection between the sulcus and the cingulum, runs diagonally to the anterior right side, and then it turns counterclockwise around the apex, forming a wide transversal loop and ending near the right side of its origin. Hypocone is smoothly truncate and slightly bilobate due to the sulcus extension until the antapex. Cingulum is descending and displaced by 1.5-2 cingulum widths. Numerous small, yellow-brownish chloroplasts, with many of them radiating from two large pyrenoids, are equatorially located with one on each side of the sulcus. Peridinin occurs as the major light-harvesting accessory pigment. Nucleus is more or less centered in the epicone of the cell.

Holotype: Figure 1 of culture VGO864, isolated from La Fosca beach, located on the Mediterranean coast of Catalonia, Spain. The culture was deposited in two cultures collections (CCVIEO and CCMP3277). Sequences were deposited to GenBank under the accession numbers FN647670 (ITS) and FN647673 (LSU).

Isotype: Figure 2F.

Type locality: La Fosca beach, Catalonia, Spain (Fig. 3) $\left(41^{\circ} 51^{\prime} 29^{\prime \prime} \mathrm{N}, 3^{\circ} 08^{\prime} 40^{\prime \prime} \mathrm{E}\right)$.

Etymology: Named after Costa Brava, the coast where this species produces blooms.

Distribution: NW Mediterranean Sea.

Habitat and ecology: Marine plankton. High cell densities $\left(>10^{6}\right.$ cell $\left.\cdot \mathrm{L}^{-1}\right)$ of $B$. bravensis have been detected in coastal waters during the summer months (June-September) at water temperatures of $20^{\circ} \mathrm{C}-27^{\circ} \mathrm{C}$ and salinities of $36.5-38.4$. This species has been found accompanying blooms of A. taylori at beaches located inside semi-enclosed bays. In laboratory cultures, B. bravensis produces mucus.

External cell morphology. The cells are slightly elongated and dorsoventrally flattened (Fig. 2C), $26.9 \pm 3 \mu \mathrm{m}(22-35.4 \mu \mathrm{m}, n=50)$ long and $20.1 \pm$ $2.3 \mu \mathrm{m} \quad(16-25.3 \mu \mathrm{m}, n=50)$ wide. The length/ width ratio ranges from 1.2 to $1.5(n=50)$. The epicone and hypocone are similar in length (Fig. 2A, $\mathrm{D}$, and $\mathrm{E}$ ). The sulcus extends to the antapex sometimes giving the hypocone a slightly bilobate shape (Fig. 2A, D, and E). The apex is generally rounded and frequently has a slight protuberance that is limited by the apical groove (Figs. 2A and B; 4, B and $\mathrm{E})$. The descending cingulum is deep and wide and displaced by 1.5-2 cingulum widths, which represent $16 \%$ to $26 \%$ of the body length (Fig. $4 \mathrm{~A}$ and B). The sulcus has a small intrusion in the epicone and
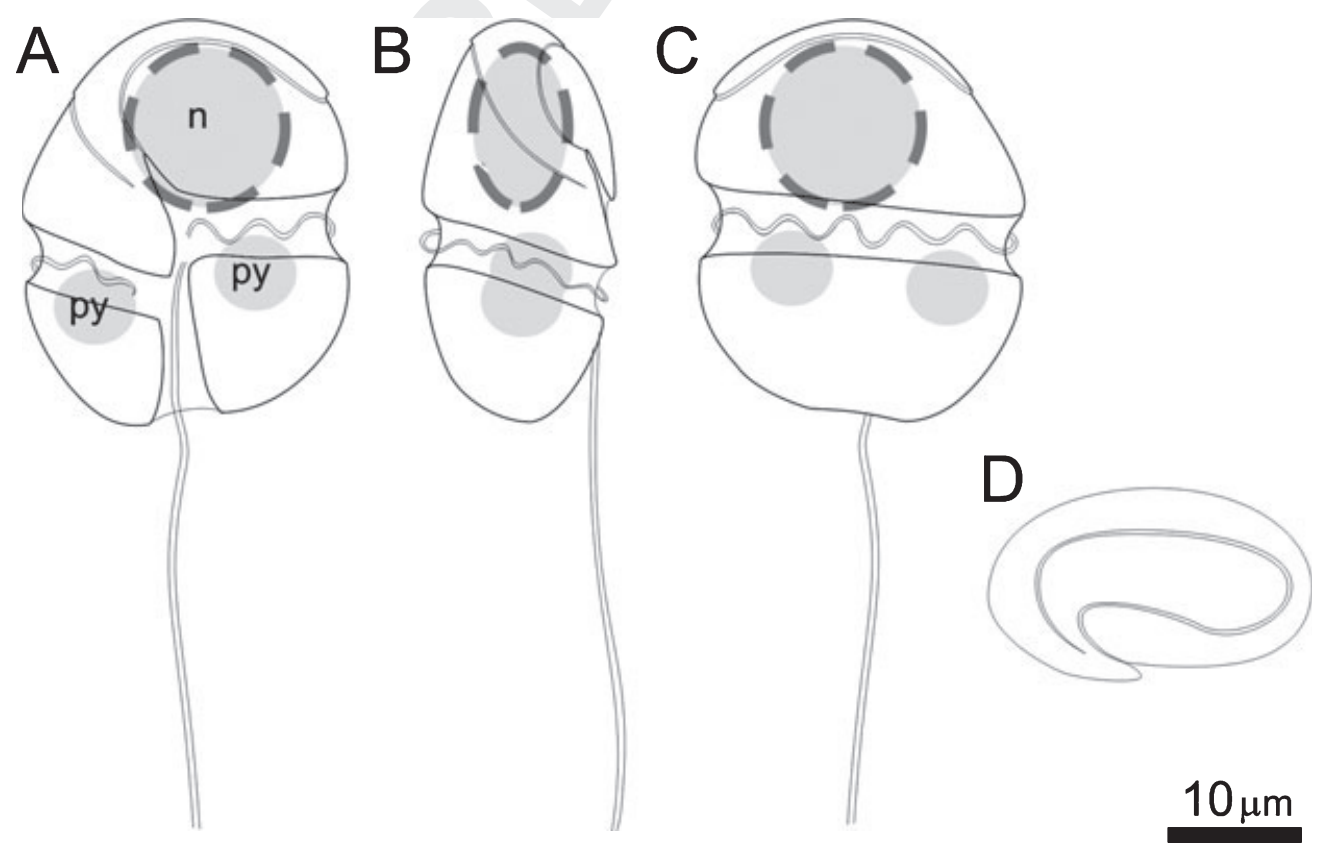

FIG. 1. Schematic representation of Barrufeta bravensis showing the position of the (n) nucleus and the (py) pyrenoids: (A) ventral, (B) lateral, (C) dorsal, and (D) apical views. 

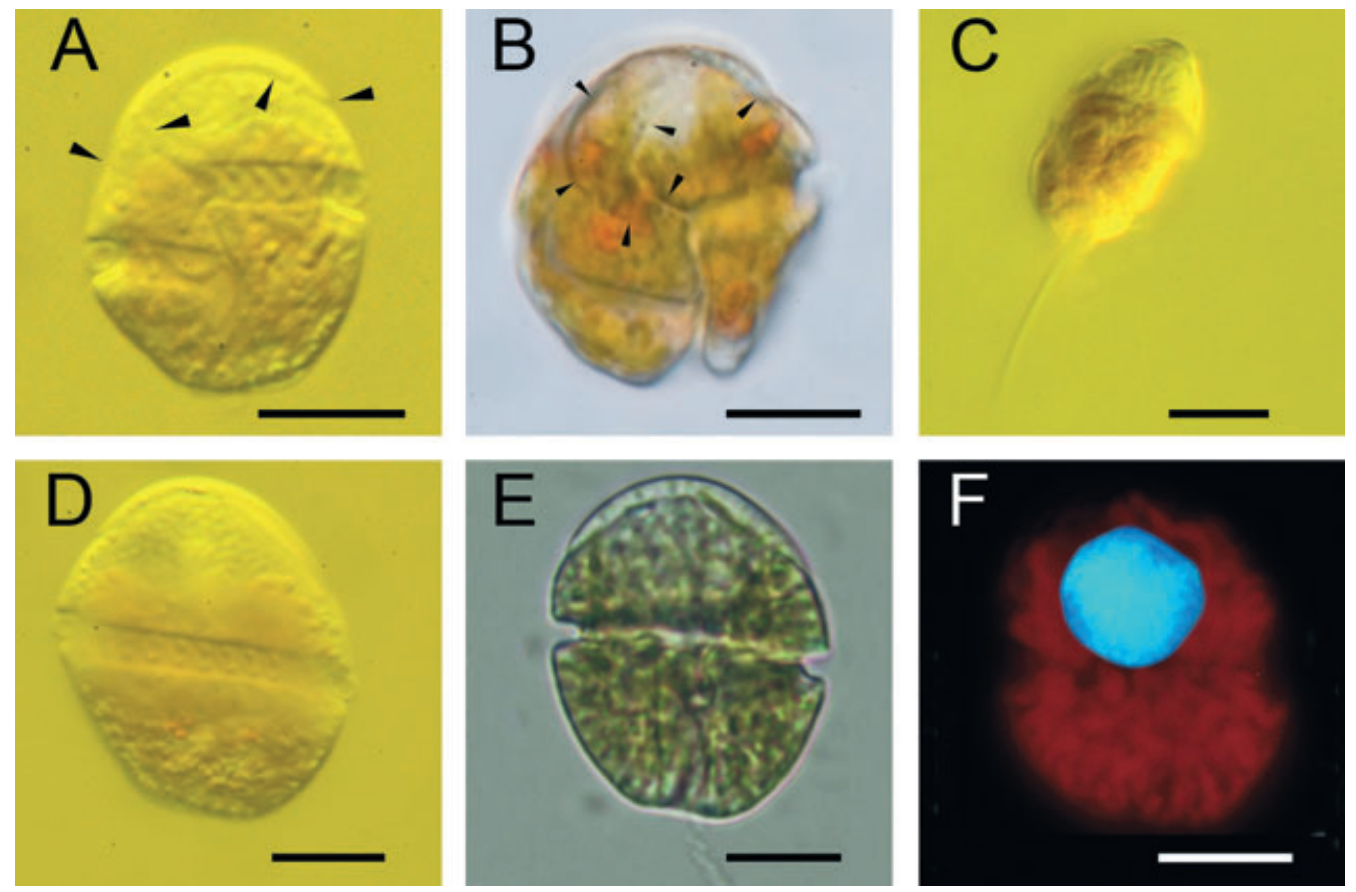

FIG. 2. Light micrographs of vegetative cells. (A-B) Ventral views showing the apical groove (arrowheads); (C) lateral view; (D-E) dorsal views; (F) epifluorescence image showing DAPI-stained nucleus and autofluorescent chloroplasts. Scale bars, $10 \mu \mathrm{m}$. DAPI, 4',6-diamidino-2-phenylindole.

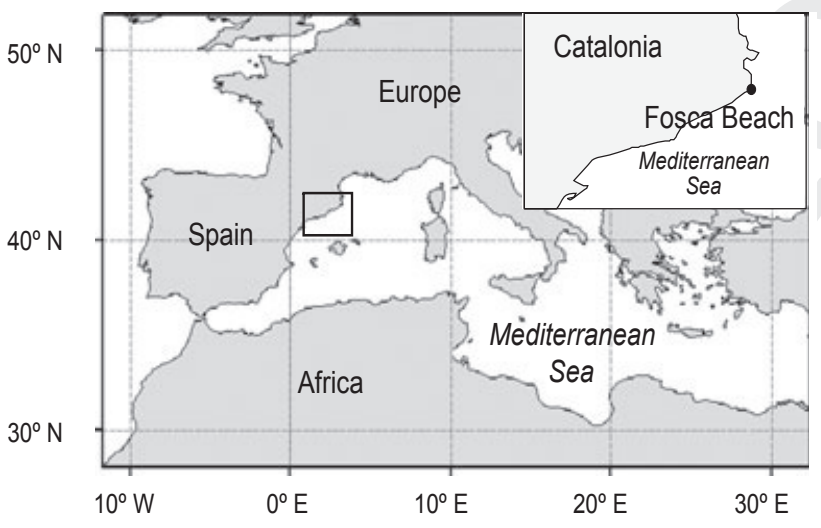

FIG. 3. Location of the sampling area, La Fosca beach.

runs deep and straight to the antapex. The epicone has an apical groove, Smurf-cap shaped, running counterclockwise around the apex. The proximal part of the groove starts at the intrusion of the sulcus in the epicone and then ascends diagonally for a short distance toward the right anterior side of the cell. The groove then turns toward the left and crosses a large part of the epicone across the ventral part of the cell, surrounds the apex of the cell, and returns parallel to the cingulum across the dorsal side of the epicone. Lastly, it turns toward the ventral part, finishing near its origin, without reaching to the sulcus of the cell (Figs. 1A-D; 2A, B and D; 4A-E). The apical groove consists of three elongated vesicles, the middle one ornamented with small knobs (Fig. 5A). The cell surface is covered with polygonal amphiesmal vesicles (usually quadrangular or pentagonal) that do not show a regular pattern, whereas the border of the girdle presents an array of well-aligned rectangular vesicles (Fig. 4F). The longitudinal flagellum varies from 1 to 1.5 times the body length.

For purpose of comparison, the structure of the apical groove of G. impudicum is shown in Figure 5B and C. Its apical groove consists of three elongated vesicles; the lateral ones are ornamented with a line of small knobs. This morphological detail was not included in the original description of this species.

Resting cyst morphology. Cysts of B. bravensis were observed in cultures. The resting cysts are flattened and range in shape from circular (21.8-29.6 $\mu \mathrm{m}$ diameter; $n=10)$ to oval $(25.4-34.9 \mu \mathrm{m}$ length, 22.3-30 $\mu \mathrm{m}$ width; $n=12)$ and occasionally irregular, as seen in the frontal view (Fig. 6A and B). The cyst is double-walled, smooth, and thick, with whitegrayish granular contents and one or more orange spots. The cysts are covered by a transparent substance that takes irregular forms. These mucoid cysts are usually strongly stuck to the bottom of the wells in culture conditions.

Cell ultrastructure. The almost spherical nucleus $(\sim 10.5 \mu \mathrm{m}$ in diameter $)$ is situated in the epicone and, as seen in lateral and ventral view of the cell, centered (Figs. 2F; 7A and B). It is a typical dinokaryon with permanently condensed chromosomes and 
FIG. 4. Scanning electron micrographs of strain of Barrufeta bravensis. Arrowheads point to the apical groove. (A) Ventral view of a cell and (B) of a cell with a slight protuberance. (C) Epicone and (D) epicone showing the nearly complete apical groove (arrowheads). (E) Dorsal view of a cell. (F) The detail of the cell surface shows the polygonal amphiesmal vesicles. Arrows point to the border of the cingulum, made up of a line of rectangular vesicles Scale bars, $10 \mu \mathrm{m}$ (unless otherwise indicated)
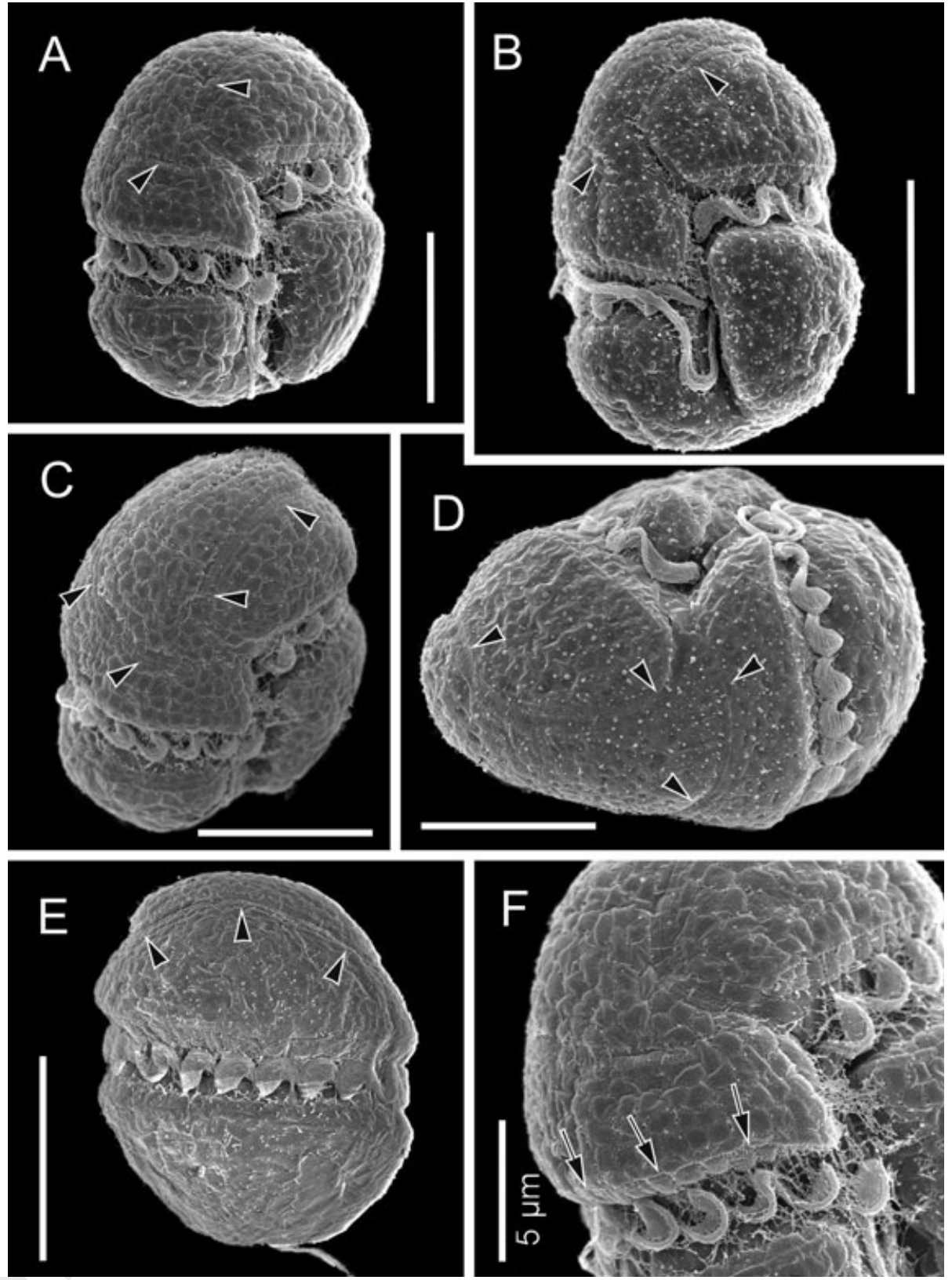

with the presence of a nucleolus (Fig. 8G). Golgi apparatus was observed adjacent to the nucleus (Fig. 8I). A structure resembling vesicular chambers of the nuclear envelope was observed in some cells (Fig. 8H), although nuclear pores were not observed in it. Two large and almost spherical pyrenoids are equatorially located, one on each side of the sulcus (Fig. 7A-D). Chloroplasts are numerous, small, elongated and radially arranged (Figs. 2F, 7D and 8A) giving the cell a yellow-brownish appearance. Many of the chloroplasts radiate from the pyrenoids to the cell periphery (Fig. 7A, C, and D). Thylakoids are stacked generally in fours to form lamellae (Fig. 8B). Many lengthened vacuoles with electron-transparent contents are radially distributed and inserted in between the chloroplasts; they occupy a large part of the distal area of the cell (Fig. 7D). The vermiform vesicles situated beneath the amphiesma have a fibrillar content that is densely packed in the middle; these vacuoles are probably mucocysts (Figs. 7A and 8E). Another kind of mucocysts, wider than the first type and oval in shape, was observed under amphiesma (Fig. 8F). Trichocysts are abundant and distributed throughout the cell. These extrusomes are composed of an apical cap, a neck, and a dense body that is quadrangular shaped in cross-section (Fig. 8C). Both the neck and the body possess an external striated cover (Fig. 8E). In addition, the cells contain lipid droplets and starch grains scattered throughout the 

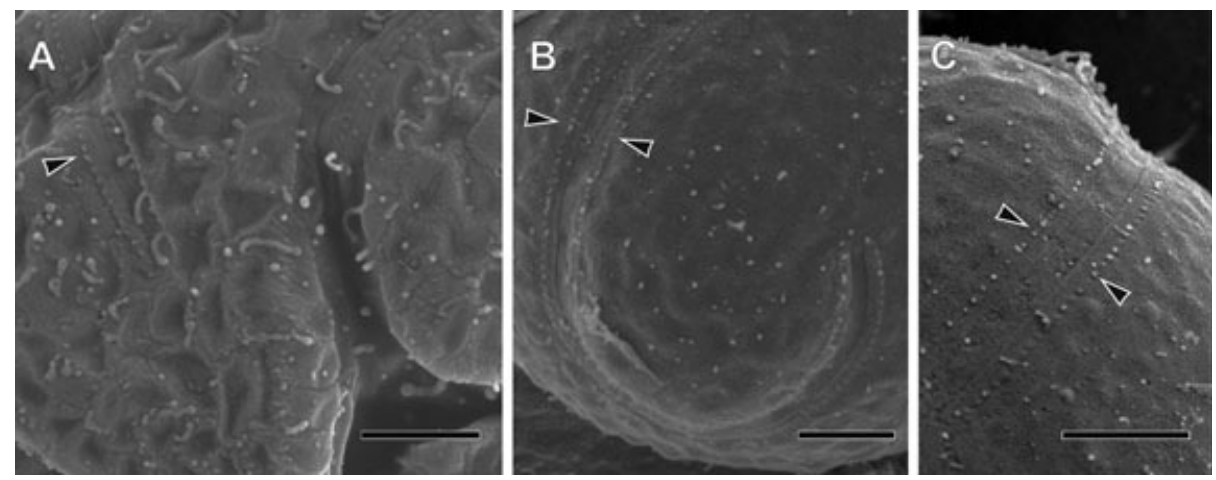

FIG. 5. Scanning electron micrographs show (A) a detailed view of the apical furrow in Barrufeta bravensis, including three elongated vesicles. The middle one is ornamented with small knobs (arrowhead). (B, C) Details of the apical furrow in Gymnodinium impudicum strain GYlVA (used for the species description). The furrow consists of three elongated vesicles; the lateral ones are ornamented with a line of small knobs (arrowheads). Scale bars, $2 \mu \mathrm{m}$.
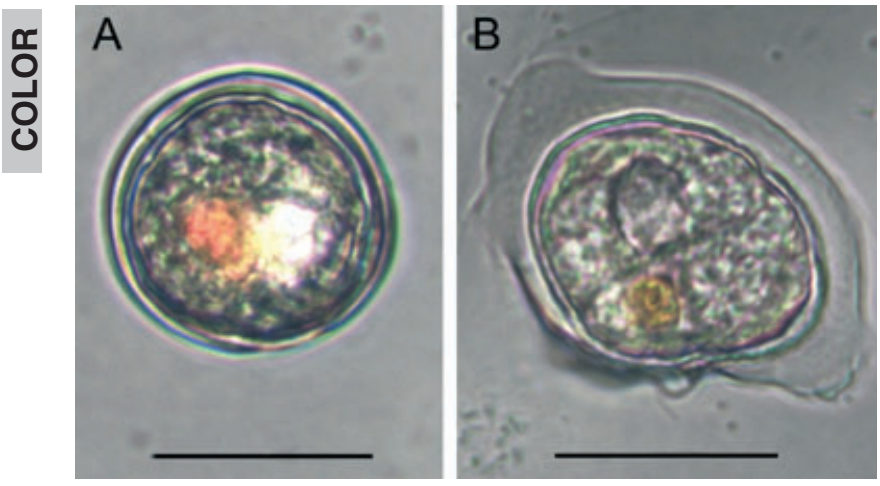

FIG. 6. Light micrographs of the (A) circular-shaped and (B) oval-shaped resting cysts of cultured Barrufeta bravensis, as seen in a frontal view. Scale bars, $20 \mu \mathrm{m}$.

cytoplasm, as well as mitochondria with tubular christae (Fig. 9D).

Spherical food-vacuole-like structures measuring $\sim 2 \mu \mathrm{m}$ in diameter were observed in some cells (Figs. 7B and 9B); their contents were similar in size to an unknown photosynthetic stramenopile present in the culture VGO864 used for TEM analysis (Fig. 9C). These structures were mainly located in the central area of the dinoflagellate cell.

The amphiesma is composed of flattened vesicles that contain a thin layer of electro-opaque material. Cortical microtubules are present under the amphiesmal vesicles in groups of two or three but sometimes more (Fig. 8D).

The pusular system is not very complex. This kind of pusular system was described by Dodge (1972) as a "pusule with collecting chamber which branches from the flagellar canal." It consists of a prolonged collecting chamber that is surrounded by numerous pusular vesicles which are joined to it. This collecting chamber branches from the flagellar canal of longitudinal flagellum (Fig. 9A).
Pigments composition. As seen in the HPLC chromatogram, the pigment profile of $B$. bravensis strain VGO864 (Fig. 10) was characteristic of peridinincontaining dinoflagellates (Jeffrey et al. 1975), with chl $c_{2}$ as the major accessory chl (chl $c_{2}:$ chl $a=0.20$ ), traces of $\mathrm{Mg}$-2,4-divinyl pheporphyrin (MgDVP:chl $a=0.01$ ), and no chl $c_{1}$. Diadinoxanthin was the major carotenoid (Diadino:chl $a=0.58$ ) followed in relative importance by peridinin (Per:chl $a=0.40$ ), dinoxanthin (Dino:chl $a=0.23)$, and diatoxanthin (0.03). Two unknown carotenoids $\left(t_{\mathrm{R}}=26.00\right.$ and $\left.29.00 \mathrm{~min}\right)$ sharing similar spectra $\left(\lambda_{\max }:[424], 453,477 \mathrm{~nm}\right)$ were also detected in minor amounts (pigment to chl $a$ ratios of 0.05 and 0.02 , respectively).

Toxin analyses. No PSP toxins were detected by HPLC with fluorescence detection or by MBA. The PBS and $\mathrm{HCl}$ extracts did not show any hemolytic activity. Lipid-soluble toxins were not tested.

Fatty acid composition. B. bravensis shows the major concentration in saturated fatty acids as a stearic acid C18:0 and palmitic acid C16:0 (4.53\% and $2.30 \%$, respectively) (Table 1 ). The second most important lipids, monounsaturated C16:1 $n 7$ and C18: $1 n 9$, were present at low concentrations $(1.22 \%$ and $1.78 \%$, respectively). All polyunsaturated fatty acids (PUFAs) were detected in concentrations of $<1 \%$. The results of fatty acids analyses of other unarmored species cultured under the same culture conditions (A. sanguinea, $G$. microreticulatum, $G$. catenatum, G. impudicum, $K$. brevis) are shown for comparison purposes in Table 1. Differences in the fatty acid profile, in addition to their percentage, have been observed between Barrufeta and other related genera such as Gymnodinium. The fatty acid profile of $K$. brevis was similar to that of B. bravensis in terms of percentages and lipid content. For example, C12:0 was detected only in B. bravensis and $K$. brevis but not in any of the three Gymnodinium species or in the A. sanguinea, despite identical culture conditions. For C14:1, the opposite case was 
FIG. 7. General ultrastructure of Barrufeta bravensis. (A) Longitudinal section of a cell shows the arrangement of the main organelles: (ch) chloroplast, (m) mucocyst, (n) nucleus, (pu) pusule, (py) pyrenoid, and (v) vesicle. (B) Lateral view of the cell. (C) Transverse section of the hypocone shows the two pyrenoids and the pusular system. (D) Slanting longitudinal section of a cell shows the chloroplasts radiating from the pyrenoids to the cell periphery. Scale bars, $5 \mu \mathrm{m}$.
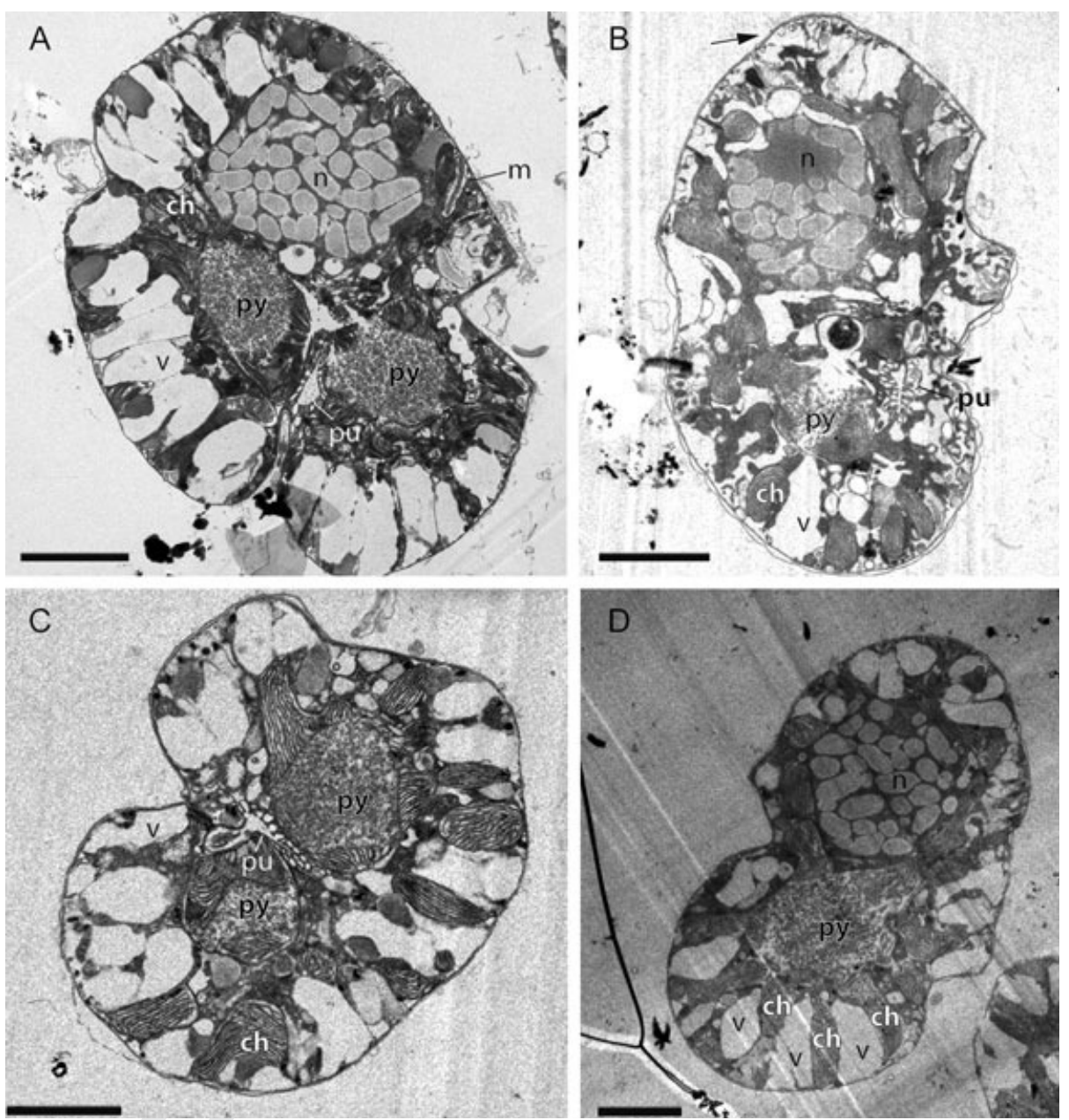

true; this fatty acid was not detected in Barrufeta but was present in the other three genera. The percentage of palmitoleic acid (C16:1n7) was higher in Gymnodinium and Akashiwo than in Barrufeta and Karenia. The percentages of PUFA C18:2 and saturated C18:0 measured in Barrufeta were also different from those in Gymnodinium, Karenia, and Akashiwo. In addition, Gymnodinium had an important concentration of saturated lipids, with a percentages ranging between $37.4 \%$ and $42.1 \%$ depending on the particular strain. This amount was almost 3-fold higher than the amount in B. bravensis, as shown in Table 1.

Molecular and phylogenetic analysis. The final alignment of $B$. bravensis with $O$. marina CCMP604 as outgroup was $647 \mathrm{bp}$ in length $(\mathrm{C}, 24.60 \%$; $\mathrm{T}, 29.06 \%$; A, $19.69 \%$; G, 26.65\%) with 607 polymorphic sites and a transition/transversion ratio of 1.6 for the 5.8S rDNA-ITS gene sequences. With A. affine as the outgroup, the aligned sequence was $722 \mathrm{bp}$ in length $(\mathrm{C}, 20.46 \%$; $\mathrm{T}, 26.34 \%$; A, 24.31\%; G, $28.89 \%$ ), with a transition/transversion ratio of 1.6 and 601 polymorphic sites for the LSU rDNA gene sequences.
As substantial identity was determined across NJ, MP, and ML analyses, with only minor differences, only the ML phylogenetic tree is shown (Figs. 11 and 12). According to the ITS-5.8S rDNA phylogeny (Fig. 11), the first lineage delineated by the outgroup comprised two species, A. affine and Coolia monotis Meunier. The ITS-5.8S rDNA phylogeny provided evidence of a major cluster within the one that included the new genus, Barrufeta. All B. bravensis isolates constituted a distinct and clearly separated group, which was a sister clade of two other genera represented by L. viride and G. impudicum. This grouping of two sister clades was supported by high bootstrap values. $B$. bravensis was included in the clade called by some authors as "Gymnodinium sensu stricto clade" together with Lepidodinium and Gymnodinium species. The tree inferred from the data and from model setting showed that different species of the Gymnodiniales were separated into several clades.

Phylogenetic analysis of the sequence generated from the LSU rDNA (Fig. 12) showed that B. bravensis formed a homogeneous group as a sister clade of Gymnodinium dorsalisulcum (Hulburt, J. A. McLaughlin et Zahl) S. L. Murray, de Salas and Hallegr; this 

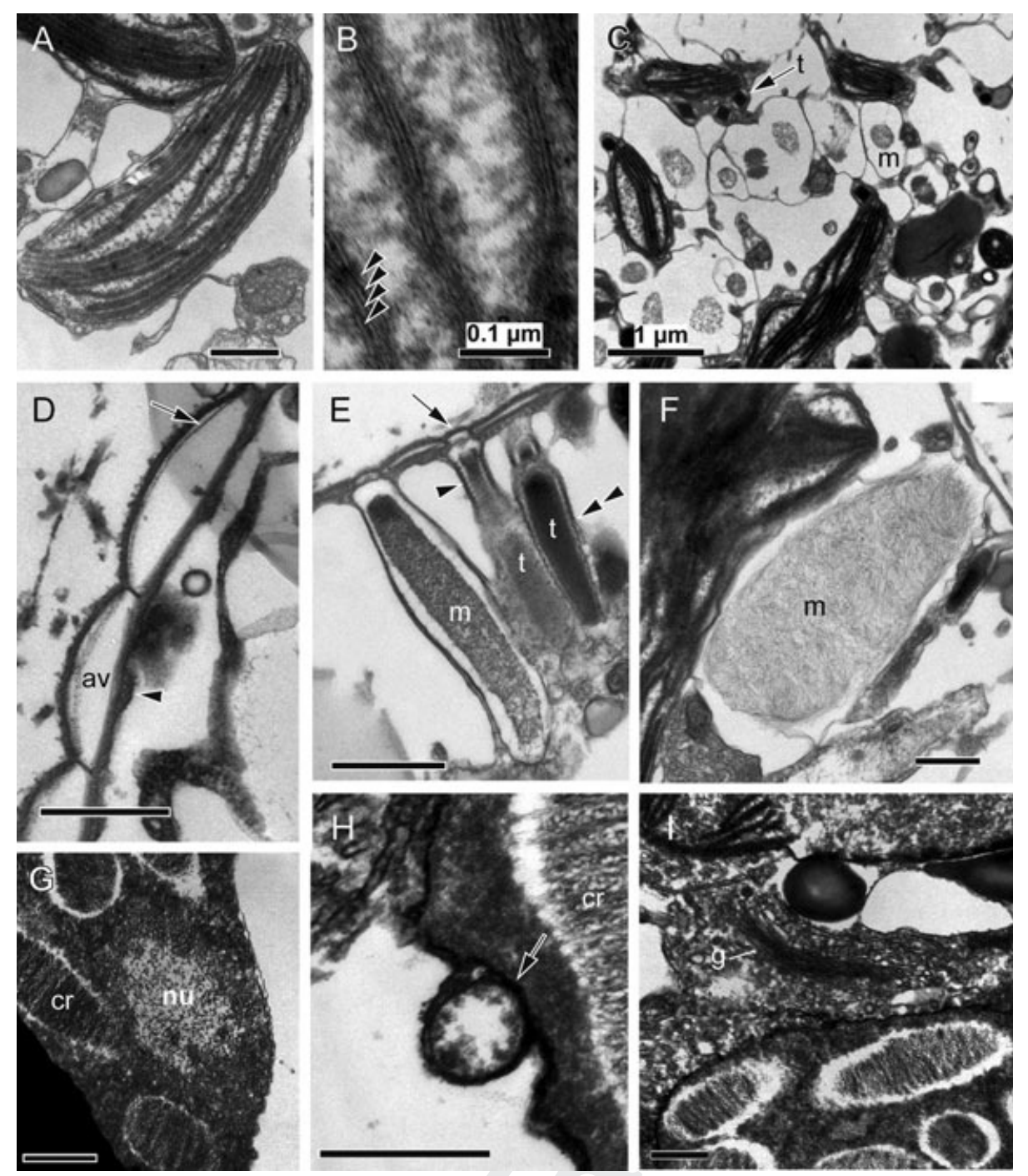

FIG. 8. Transmission electron micrographs of Barrufeta bravensis. (A) Whole chloroplast. (B) Detail of a chloroplast showing thylakoids grouped in fours (arrowheads) to form lamellae. (C) Section of a subsuperficial area of the cell, showing chloroplasts, trichocysts ( $\mathrm{t}$ ), and mucocyst-like vesicles $(\mathrm{m})$ in a transverse section. (D) A transverse section of amphiesma shows the amphiesmal vesicle (av), which contains platelike material (arrow); the arrowhead indicates cortical microtubules in groups of two or three. (E) Longitudinal section of two trichocysts (t), showing the cap (arrow) and the striation in both the neck (arrowhead) and body (double arrowhead); a vermiform mucocyst $(\mathrm{m})$ with dense material in its core also has a cap. (F) Oval mucocyst and (G) detail of the nucleus, including the nucleolus (nu) and chromosome (cr). (H) In a detailed view of the nucleus, a chromosome and a structure resembling a vesicular chamber (arrow). (I) Part of the Golgi (g) adjacent to the nucleus. Scale bars, $0.5 \mu \mathrm{m}$ (unless otherwise indicated).
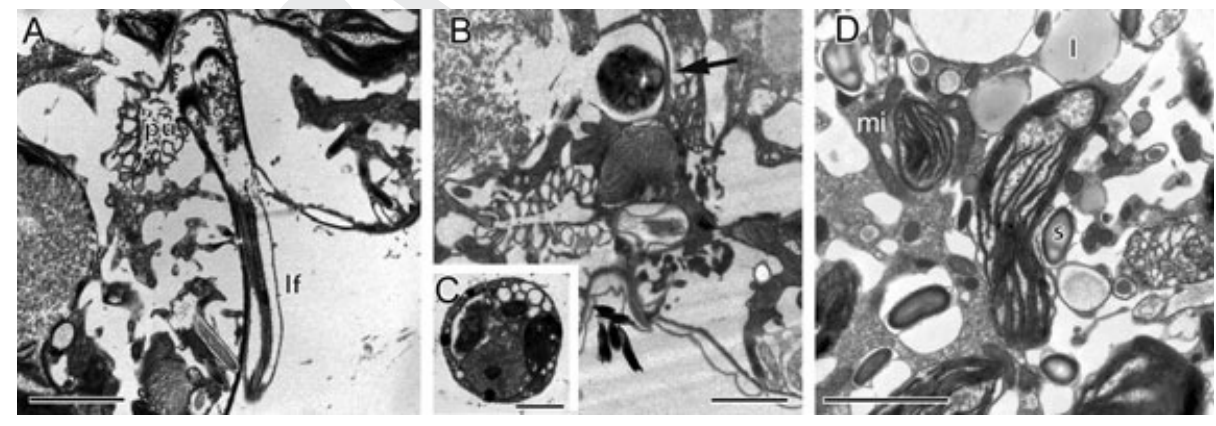

FIG. 9. Transmission electron micrographs of Barrufeta bravensis. (A) The pusular system (pu) connects with the longitudinal flagellar canal; longitudinal flagella (lf). (B) Food-vacuole-like structure (arrow). (C) Unknown photosynthetic stramenopile cultured with Barrufeta. The size of the unknown photosynthetic stramenopile is similar to that of the content of the food-vacuole-like structure. Scale bar, $1 \mu \mathrm{m}$. (D) Micrograph of the cytoplasm, showing droplets of lipids (1), starch grains (s), and mitochondrion (mi). Scale bars (A, B, D), $2 \mu \mathrm{m}$.

grouping was supported by high bootstraps values in the NJ and ML analyses. B. bravensis was included in the "Gymnodinium sensu stricto clade," which was partially resolved. In the LSU phylogeny based on
A. affine as outgroup, two major groups diverged: one group including different taxa segregated at different branching orders and a second one, "Gymnodinium sensu stricto clade," which seemed better 


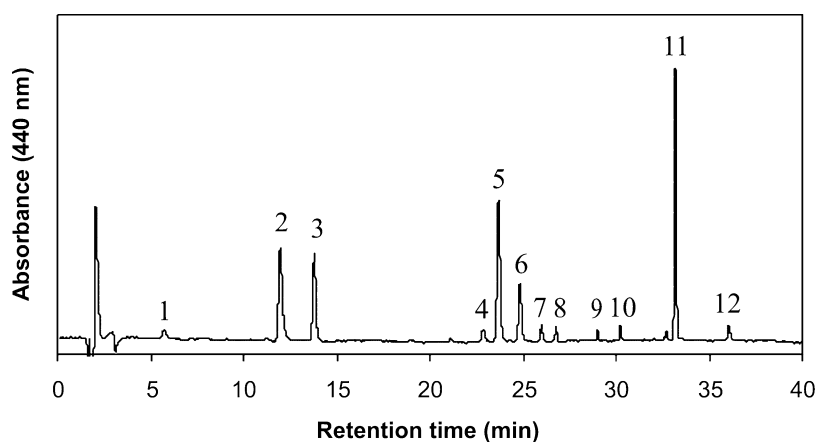

FIG. 10. HPLC chromatogram of pigments from Barrufeta bravensis strain VGO864. Peak identification: (1) peridininol, (2) chl $c 2$, (3) peridinin, (4) diadinochrome, (5) diadinoxanthin, (6) dinoxanthin, (7) unknown carotenoid, (8) diatoxanthin, $(9,10)$ unknown carotenoids, (11) chl $a$, (12) $\beta, \beta$-carotene. Detection by absorbance at $440 \mathrm{~nm}$.

resolved. Within the first main grouping, the first cluster included Tovellia, Amphidinium and Jadwigia. The second cluster consisted of two further groups: one group that comprised Akashiwo, Biecheleria, Gyrodinium falcatum, and Ceratium fusus together with the sister taxon of Cochlodinium fulvescens; the other group included three genera belonging to the family Kareniaceae (Karenia, Takayama, Karlodinium) as a sister branch of one that included Gymnodinium instriatum and Gyrodinium spirale. In the LSU phylogeny, the second main grouping "Gymnodinium sensu stricto clade" included two different clusters. One cluster consisted of two sister clades, one of them composed of different species of Gymnodinium including the type species G. fuscum (Ehrenb.)
F. Stein, and the other one composed of the genus Lepidodinium, Barrufeta, and two species of Gymnodinium; the other cluster also included genera such as Polykrikos, Gymnodinium and Pheopolykrikos with the exception of Dissodinium (Blastodiniales).

\section{DISCUSSION}

Daugbjerg et al. (2000) identified both the shape of the apical groove and pigments composition as critical features allowing the differentiation of unarmored dinoflagellate genera, as they were consistent with phylogenetic trees based on rDNA sequencing. This approach resulted in the redescribed genera Gymnodinium and Gyrodinium as well as new genera, such as Akashiwo distinguished by differences in the shape of the apical groove (Daugbjerg et al. 2000). Another genus, Takayama, with yet a different apical groove shape was described later (de Salas et al. 2003). The shape of the apical groove of new genus Barrufeta also differs from that of other gymnodinioids. Furthermore, referring to the different kinds of apical-furrow apparatuses described in the literature (Hansen and Daugbjerg 2009, Moestrup et al. 2009a, b), we made a detailed structural comparison between the apical groove of Barrufeta and that of a species belonging to the genus Gymnodinium, $G$. impudicum. Although both contained three elongated vesicles, small knobs ornamented the central vesicle in $B$. bravensis, whereas in $G$. impudicum the lateral vesicles were ornamented. This is the first time that this difference has been noted. However, more species belonging to the two genera need to

TABLE 1. Relative abundance $(\%)$ of fatty acids in different marine unarmored dinoflagellates cultured under the same conditions and harvested in the same growth phase.

\begin{tabular}{|c|c|c|c|c|c|c|}
\hline Fatty acids & $\begin{array}{c}\text { Barrufeta } \\
\text { bravensis } \\
\text { (VGO864) }\end{array}$ & $\begin{array}{c}\text { Karenia } \\
\text { brevis } \\
\text { (CCMP2281) }\end{array}$ & $\begin{array}{l}\text { Gymnodinium } \\
\text { microreticulatum } \\
\text { (VGO328) }\end{array}$ & $\begin{array}{l}\text { Gymnodinium } \\
\text { catenatum } \\
\text { (Est14H5) }\end{array}$ & $\begin{array}{l}\text { Gymnodinium } \\
\text { impudicum } \\
\text { (VGO665) }\end{array}$ & $\begin{array}{l}\text { Akashiwo } \\
\text { sanguinea } \\
\text { (VGO626) }\end{array}$ \\
\hline C12:0 & 0.28 & 0.1 & 0.0 & 0.0 & 0.0 & 0.0 \\
\hline C14:1 & 0.0 & 0.5 & 1.0 & 1.1 & 1.0 & 1.3 \\
\hline C14:0 & 0.24 & 1.0 & 1.0 & 1.3 & 1.7 & 2.0 \\
\hline C15:0 & 0.12 & 0.2 & 0.8 & 1.1 & 2.3 & 0.6 \\
\hline $\mathrm{C} 16: 1 n 7$ & 1.22 & 1.3 & 6.4 & 5.9 & 4.9 & 8.0 \\
\hline C16:0 & 2.30 & 2.8 & 14.7 & 14.0 & 13.2 & 18.0 \\
\hline C17:0 & 0.17 & 0.1 & 0.7 & 0.5 & 1.0 & 0.5 \\
\hline C18:5n3 & 0.24 & 0.5 & 2.9 & 1.0 & 0.5 & 1.6 \\
\hline C18:3 & 0.29 & 1.1 & 2.6 & 1.4 & 0.9 & 3.9 \\
\hline C18:2 & 0.95 & 0.0 & 0.0 & 0.0 & 0.0 & 0.0 \\
\hline $\mathrm{C} 18: \ln 9$ & 1.78 & 1.3 & 6.6 & 7.0 & 7.0 & 4.3 \\
\hline C18:0 & 4.53 & 3.6 & 19.9 & 23.4 & 23.9 & 13.1 \\
\hline C20:5n3 & 0.21 & 0.0 & 2.5 & 0.0 & 0.0 & 3.4 \\
\hline $\mathrm{C} 20: 4$ & 0.0 & 0.0 & 7.8 & 1.3 & 0.0 & 12.2 \\
\hline C20:0 & 0.10 & 0.10 & 0.3 & 0.0 & 0.0 & 0.6 \\
\hline C22:0 & 0.0 & 0.0 & 0.0 & 0.0 & 0.0 & 0.3 \\
\hline C24:0 & 0.0 & 0.0 & 0.0 & 0.0 & 0.0 & 0.4 \\
\hline SFA & 7.7 & 7.9 & 37.4 & 40.3 & 42.1 & 35.5 \\
\hline MUFA & 3.0 & 3.1 & 14.0 & 14.0 & 12.9 & 13.6 \\
\hline PUFA & 1.7 & 1.6 & 15.8 & 3.7 & 1.4 & 21.1 \\
\hline
\end{tabular}

SFA, saturated fatty acid; MUFA, monounsaturated fatty acid; PUFA, polyunsaturated fatty acid. 


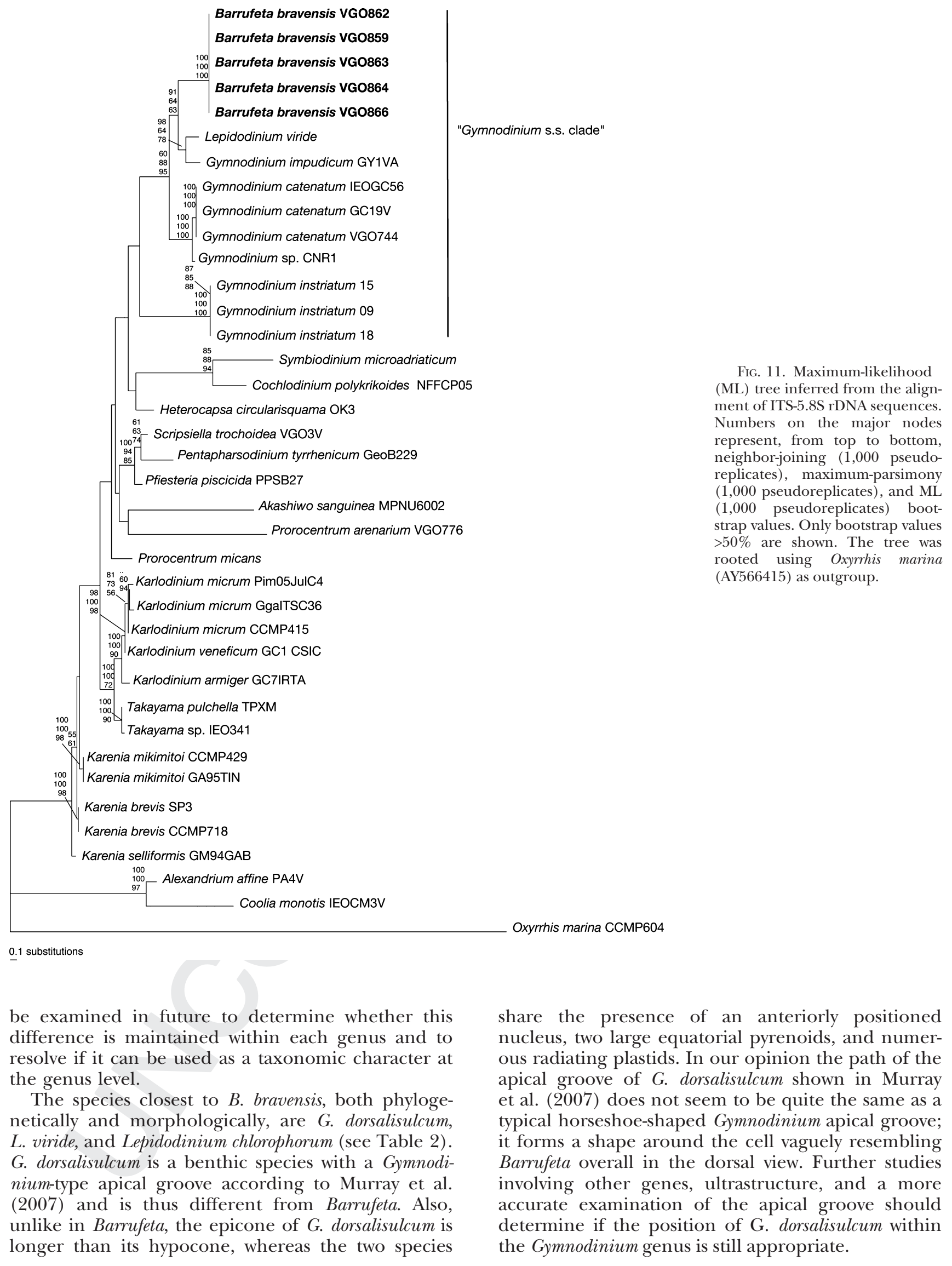

\begin{abstract}
(ML) tree inferred from the alignneighbor-joining (1,000 pseudoeplicates), maximum-parsimony (1,000 pseudoreplicates), and ML 1,000 pseudoreplicates) bootvalues. Only bootstrap value $50 \%$ are shown. The tree was (AY566415) as outgroup.
\end{abstract}


Fig. 12. Maximum-likelihood (ML) tree inferred from alignment of the D1/D2 domains of the LSU rDNA sequences. Numbers on the major nodes represent, from top to bottom, neighbor-joining $\quad(1,000$ pseudoreplicates), maximum-parsimony (1,000 pseudoreplicates), and ML (1,000 pseudoreplicates) bootstrap values. Only bootstrap values $>50 \%$ are shown. The tree was rooted using Alexandrium affine (AY294612) as outgroup.

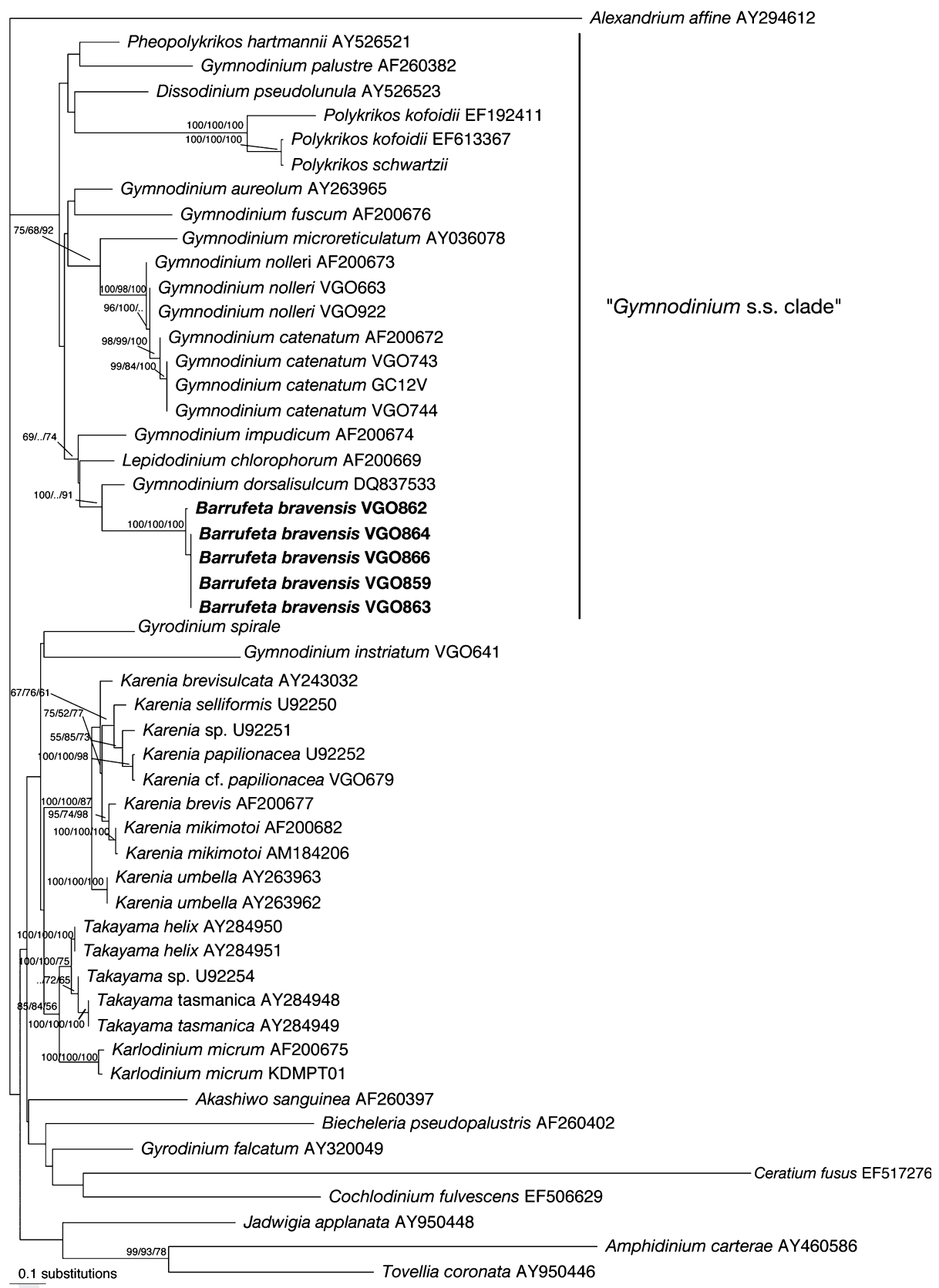

Both Lepidodinium species have an apical groove of the Gymnodinium type, and their pigments derive from Chlorophyta, as deduced from plastid-encoded gene phylogeny (Takishita et al. 2008). Although several other dinoflagellate genera included within Gymnodiniales, such as Karenia, Karlodinium, and Takayama, acquired their chloroplasts through tertiary endosymbiosis from haptophytes (Tengs et al. 2000, de Salas et al. 2003, Garcés et al. 2006), Barrufeta is a typical peridinin-containing dinoflagellate and is thus similar to Gymnodinium but different from Lepidodinium. In addition to the $B$. bravensis strain VGO864, the other strains that were analyzed (VGO859 and VGO860) were observed to have similar pigment patterns and ratios, with diadinoxanthin as the dominant carotenoid, followed by peridinin. This result could be explained by a culture light environment prone to eliciting a photoprotection mechanism that results in a reduced proportion of the light-harvesting pigment peridinin and an increased pool of the photoprotective carotenoid diadinoxanthin.

Since Daugbjerg et al. (2000) described the Gymnodinium sensu stricto clade, several genera have been included in this clade in addition to Gymnodinium, such as Lepidodinium (Hansen et al. 2007), Polykrikos (Hoppenrath and Leander 2007), Dissodinium (Gemez et al. 2009b), Warnowia (Gemez et al. 5 


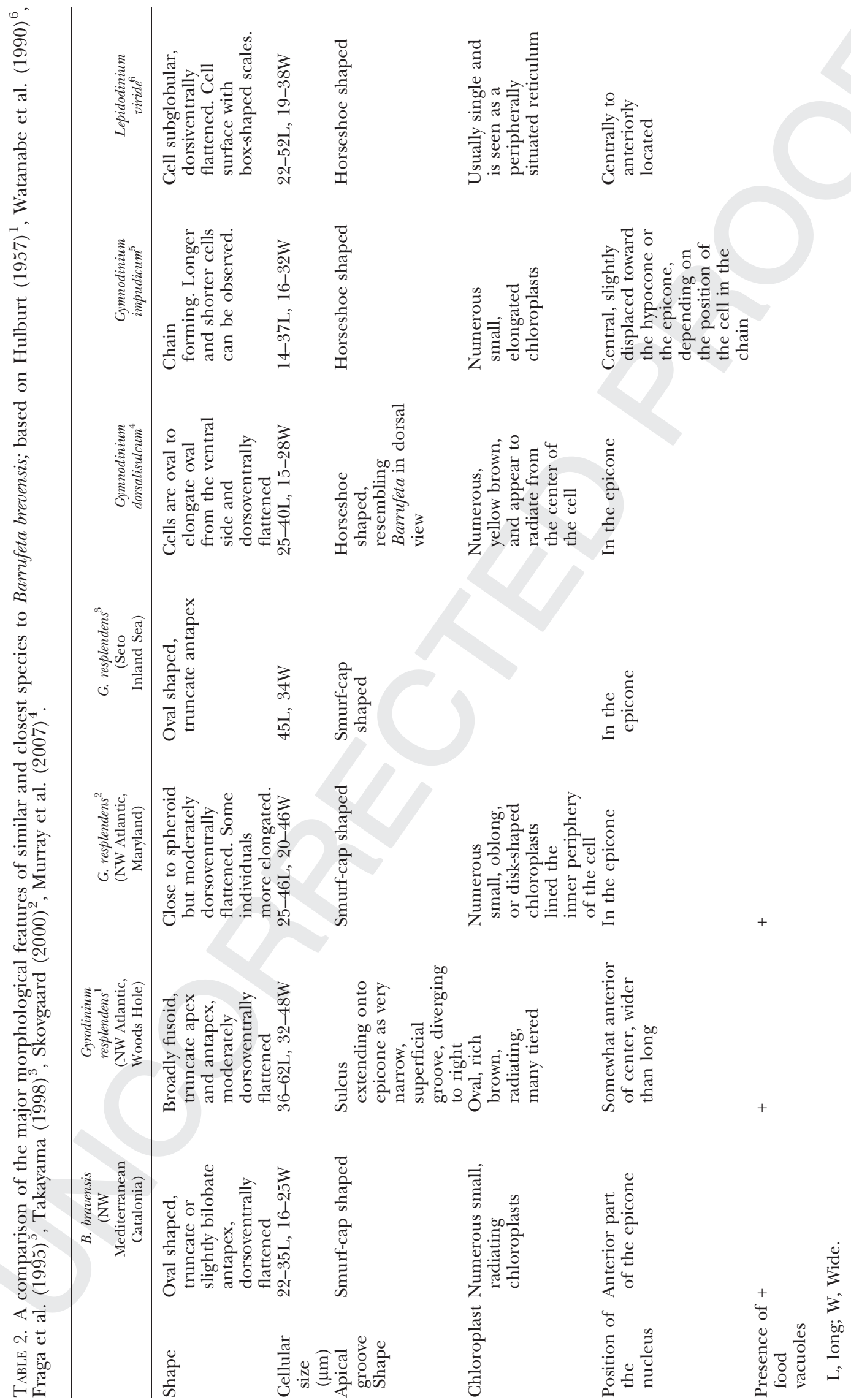


6 2009a), Nematodinium (Hoppenrath et al. 2009), Erythrosidinium (Gomez et al. 2009a), Chytriodinium (Gomez et al. 2009b), and Paragymnodinium (Kang et al. 2010); consequently, the name of this group does not seem to be at the moment the most appropriate. The new phylogenetic data on gymnodinioids together with data from the literature (e.g.,

7 Gemez et al. 2009b) show that species considered Gymnodinium are located in different branches of this clade. This fact supports the need to establish many new genera in order to include species currently considered as belonging to Gymnodinium. Species such as G. catenatum, G. nolleri, and G. microreticulatum are monophyletic, have reticulate cysts, and although their horse-shoe shaped apical groove is of the Gymnodinium type, it is slightly different from the groove of other Gymnodinium species (i.e., G. impudicum, G. dorsalisulcum, and G. fuscum). Accordingly, they should be distinguished within a new genus.

The presence of nuclear chambers and nuclear fibrous connective (NFC) have been considered characteristics of the genus Gymnodinium (Daugbjerg et al. 2000), although it has not been demonstrated in all species that Daugbjerg transferred to Gymnodinium genus. Nevertheless, both structures have also been observed in L. chlorophorum and L. viride (Hansen et al. 2007), although the NFC component is not as large. The NFC has also been detected in other dinoflagellate genera, such as Polykrikos (Bradbury et al. 1983), Actiniscus (Hansen 1993), Nematodinium (Roberts and Taylor 1995), and Biecheleriopsis (Moestrup et al. 2009b). While nuclear chambers were observed in Barrufeta, they are not as numerous as in Gymnodinium fuscum (Hansen et al. 2000b) or L. viride (Hansen et al. 2007), and nuclear pores were not observed. NFG was not seen in Barrufeta, but the presence of this structure cannot yet be ruled out entirely because unfortunately serial sections of samples were not examined with a transmission electron microscope. The large number of the vacuoles with electron-transparent contents and arranged along the periphery alternating with the chloroplast is unusual. Other highly vacuolated species are, for example, Polykrikos lebourae Herdman (Hoppenrath and Leander 2007) and Amphidinium cryophilum G. J. Wedem., L. W. Wilcox et L. E. Graham (Wilcox et al. 1982). In B. bravensis, the vacuoles with fibrillar content are probably mucocysts, similar to those observed in P. lebourae and Prorocentrum tsawwassenense Hoppenrath et B. S. Leander and consistent with the observation that $B$. bravensis is a mucus producer. The strain of Barrufeta only used in this study for TEM was accompanied by a small, unknown photosynthetic stramenopile. The observation of food-vacuole-like structures with a size similar to that of the unknown photosynthetic stramenopile and the fact that the mixed cultures grew better than the nonmixed ones led us to conclude that B. bravensis is a mixotrophic species.
There exists a major discussion about the utility of fatty acids as a chemotaxonomic tool, since these lipids show a variable profile during the growth curve and under different growth conditions (Thompson et al. 1992, Xu and Beardall 1997, Zhu et al. 1997, Xu et al. 2008). This fact, added to the different methodologies used for the analysis of fatty acids in the literature, makes most of the data from the literature uncomparable. In this work, we wanted to compare the profile of fatty acids of $B$. bravensis with those of other unarmored dinoflagellates. To avoid growth- methodology and culturerelated differences in fatty acid profiles, all of the strains examined in this study were cultured under the same conditions, examined during the same growth phase and under the same methodology. In this way, the results obtained in this work demonstrate that the fatty acids of B. bravensis, in terms of percentages and composition, are more similar to those of $K$. brevis than to those of other species more related, such as the three species of Gymnodinium analyzed.

The Barrufeta genus could include some other species previously described in the literature. This may be the case for G. resplendens (Hulburt 1957), which shares several characteristics with Barrufeta, such as the presence of numerous radiating chloroplasts (see Table 2). Hulburt (1957) described the apical groove of this species as "the sulcus extending onto the epicone as a very narrow superficial groove, diverging to the right." This is similar to the proximal part of the apical groove of Barrufeta, but the end of the apical groove of G. resplendens was not described, or its apical groove is short and only located on its ventral part. In addition, also the presence of the pyrenoids was not described, and the size of the latter species is larger than that of Barrufeta (36-62 $\mu \mathrm{m}$ length, 32-48 $\mu \mathrm{m}$ width), although smaller cells were identified as in $G$. resplendens by Campbell (1973). Daugbjerg et al. (2000), based on the apical groove of G. resplendens, suggested that this species could belong to Akashiwo, but some organisms not belonging to the latter genus have been identified as G. resplendens by other authors. A strain isolated from a brackish water (salinity 11) fish pond in Maryland, on the East Coast of the USA, and identified as G. resplendens was used by Skovgaard (2000) in a study on mixotrophy, which provided new morphological and behavioral details regarding this plastidic species. Even though Skovgaard (2000) realized that in Hulburt's drawing the apical groove did not encircle the apex of the cell, he assumed that Hulburt had overlooked this feature; based on other similarities with the original G. resplendens material, he therefore assigned his organism to this species. Our sample material was similar to that used in Skovgaard's study with respect to the shape of the apical groove, cingulum displacement, the positions and shapes of the chloroplast and nucleus, the presence of food 

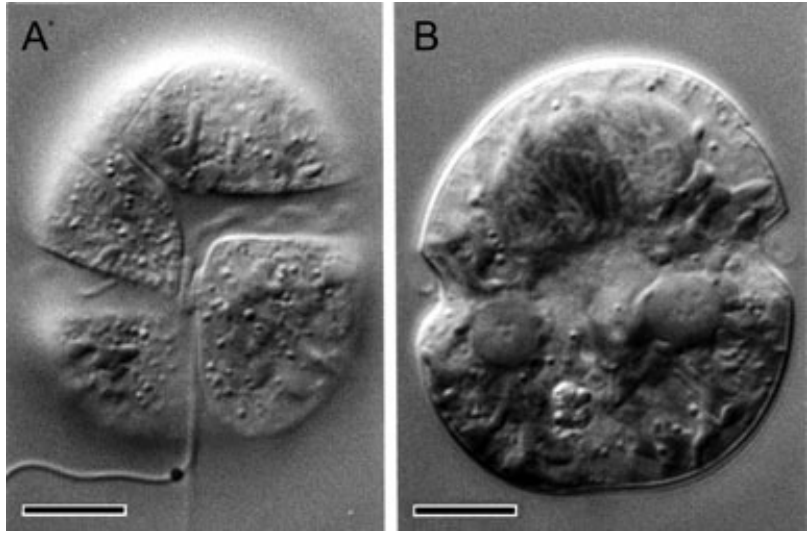

Fig. 13. (A, B) Light micrographs of Gyrodinium resplendens. Reproduced from Takayama (1998), Figs. 2 and 4, respectively, with permission. Scale bars, $10 \mu \mathrm{m}$.

vacuoles, the shape of the smooth-walled cysts, and the presence and position of two pyrenoids, which are possible to be observed in a differential interference contrast (DIC) photograph (fig. 7 in Skovgaard 2000). However, Skovgaard described cells that were generally rounded and only moderately dorsoventrally flattened, whereas $B$. bravensis cells are more elongated and more dorsoventrally flattened. Moreover, Skovgaard observed two types of cysts, the most frequent of which had a smooth surface with either a few irregular spines or without spines, while the other, a more uncommon one had a spiny wall. The surfaces of Barrufeta cysts are exclusively completely smooth, and most of them are surrounded by mucus. Other aspects of the two species, such as the salinity of the water where they were found, are also differe ${ }^{\text {In }}$ another study of 8 G. resplendens (Loeblich $\bar{\equiv} d$ Smith 1968), the reported pigment composition was consistent with our results, although, in contrast to B. bravensis, peridinin was found to be the major carotenoid (40\%) in G. resplendens, followed by diadinoxanthin $(33 \%)$. Takayama (1998) studied G. resplendens from material collected from the Seto Inland Sea and showed the complete apical groove, which had the same shape as we have described in Barrufeta. Furthermore, DIC images showed similar positions of the nucleus and of the two larepyrenoids

9 (Fig. 13). Mainly due to the proba $\overline{\bar{\nu}}$, of the incompletely described apical groove in the original report of $G$. resplendens, we cannot be sure that the G. resplendens described by Hulburt is a Barrufeta; however, the species studied as $G$. resplendens by Takayama and by Skovgaard, which are not necessarily the same one described by Hulburt, can most certainly be assigned to the genus Barrufeta.

We thank G. Forlani, F. Lamunno, and J. M. Fortuño for their technical support during SEM analyses; E. Fernández and A. García from the Unitat de Microscòpia Electrònica, Facultat de Medicina-SCT, Universitat de Barcelona for helping out with the TEM technique; A. Fernández-Villamarín and P. Rial for maintaining strains; K. Molle and W. Ran for English revision of the manuscript; A. Ollé for his help with the drawings; M. Masó for field sampling; and X. Maure for preparing the Latin descriptions. We also thank M. Montresor, R. Siano, M. Estrada, R. I. Figueroa, H. Takayama, J. M. Franco, E. Garcés, and L. Cros for their cooperation and comments. Financial support was provided by the Agència $\mathrm{Ca}-$ talana de l'Aigua (Department de Medi Ambient, Generalitat de Catalunya) and the CSIC through the contract "Plà de vigilància de fitoplàncton nociu i tòxic a la Costa Catalana," by the EU project MARPLAN (European integration of marine microplankton research) undertaken within the MarBEF EU Network of Excellence, and by CCVIEO.

Association of Official Analytical Chemists (AOAC). 1990. PSP biological method. Final action. In Hellrich, K. [Ed.] Official Methods Analysis. 15th edn. AOAC, Arlington, Virginia, pp. 881-2.

Bjørnland, T. \& Tangen, K. 1979. Pigmentation and morphology of a marine Gyrodinium (Dinophyceae) with a major carotenoid different from peridinin and fucoxanthin. J. Phycol. 15:457-63.

Bradbury, P. C., Westfall, J. A. \& Townsend, J. W. 1983. Ultrastructure of the dinoflagellate Polykrikos. 2. The nucleus and its connections to the flagellar apparatus. J. Ultrastruct. Res. 85:2432.

Campbell, P. H. 1973. Studies on brackish water phytoplankton. PhD dissertation, University of North Carolina, Chapel Hill, North Carolina, 403 pp.

Daugbjerg, N., Hansen, G., Larsen, J. \& Moestrup, O. 2000. Phylogeny of some of the major genera of dinoflagellates based on ultrastructure and partial LSU rDNA sequence data, including the erection of three new genera of unarmoured dinoflagellates. Phycologia 39:302-17.

Dodge, J. D. 1972. The ultrastructure of dinoflagellate pusule: a unique osmo-regulatory organelle. Protoplasma 75:285-302.

Dodge, J. D. 1974. A redescription of the dinoflagellate Gymnodinium simplex with the aid of electron microscopy. J. Mar. Biol. Assoc. UK 54:171-7.

Emura, A., Matsuyama, Y. \& Oda, T. 2004. Evidence for the production of a novel proteinaceous hemolytic exotoxin by dinoflagellate Alexandrium taylori. Harmful Algae 3:29-37.

Excoffier, L., Laval, G. \& Schneider, S. 2005. Arlequin ver. 3.0: an integrated software package for population genetics data analysis. Evol. Bioinform. Online 1:47-50.

Fraga, S., Bravo, I., Delgado, M., Franco, J. M. \& Zapata, M. 1995. Gyrodinium impudicum sp. nov. (Dinophyceae), a non toxic, chain-forming, red tide dinoflagellate. Phycologia 34:514-21.

Franco, J. M. \& Fernandez, P. 1993. Separation of PSPtoxins by RP-HPLC, with postcolumn reaction and fluorometric detection. Chromatographia 35:613-20.

Fuentes-Grunewald, C., Garces, E., Rossi, S. \& Camp, J. 2009. Use of the dinoflagellate Karlodinium veneficum as a sustainable source of biodiesel production. J. Ind. Microbiol. Biotechnol. 36:121524.

Garcés, E., Fernandez, M., Penna, A., Van Lenning, K., Gutierrez, A., Camp, J. \& Zapata, M. 2006. Characterization of NW Mediterranean Karlodinium spp. (Dinophyceae) strains using morphological, molecular, chemical, and physiological methodologies. J. Phycol. 42:1096-112.

Garcés, E., Mase, M. \& Camp, J. 1999. A recurrent and localized dinoflagellate bloom in Mediterranean beach. J. Plankton Res. 21:2373-91.

Gomez, F., Lopez-Garcia, P. \& Moreira, D. 2009a. Molecular phylogeny of the ocelloid-bearing dinoflagellates Erythropsidinium and Warnowia (Warnowiaceae, Dinophyceae). J. Eukaryot. Microbiol. 56:440-5.

Gemez, F., Moreira, D. \& Lepez-Garcia, P. 2009b. Life cycle and molecular phylogeny of the dinoflagellates Chytriodinium and Dissodinium, ectoparasites of copepod eggs. Eur. J. Protistol. 45:260-70.

Guillard, R. R. L. \& Hargraves, P. E. 1993. Stichochrysis inmobilisis a diatom, not a chrysophyte. Phycologia 32:234-6. 
Hansen, G. 1993. Light and electron micorscopical observations of the dinoflagellate Actiniscus pentasterias (Dinophyceae). J. Phycol. 29:486-99.

Hansen, G., Botes, L. \& De Salas, M. 2007. Ultrastructure and large subunit rDNA sequences of Lepidodinium viride reveal a close relationship to Lepidodinium chlorophorum comb. nov. (= Gymnodinium chlorophorum). Phycological Res. 55:25-41.

Hansen, G. \& Daugbjerg, N. 2009. Symbiodinium natans sp. nov.: a "free-living" dinoflagellate from Tenerife (northeast Atlantic Ocean). J. Phycol. 45:251-63.

Hansen, G., Daugbjerg, N. \& Henriksen, P. 2000a. Comparative study of Gymnodinium mikimotoi and Gymnodinium aureolum, comb. nov (= Gyrodinium aureolum) based on morphology, pigment composition, and molecular data. J. Phycol. 36:394410 .

Hansen, G., Moestrup, O. \& Roberts, K. 2000b. Light and electron microscopical observations on the type species of Gymnodinium, G. fusum (Dinophyceae). Phycologia 39:365-76.

Hernández, M. C. 1992. A simple way to encapsulate small samples for processing for TEM. J. Microsc. 168:203-6.

Hoppenrath, M., Bachvaroff, T. R., Handy, S. M., Delwiche, C. F. \& Leander, B. S. 2009. Molecular phylogeny of ocelloid-bearing dinoflagellates (Warnowiaceae) as inferred from SSU and LSU rDNA sequences. BMC Evol. Biol. 9:1-15.

Hoppenrath, M. \& Leander, B. S. 2007. Morphology and phylogeny of the pseudocolonial dinoflagellates Polykrikos lebourae and Polykrikos herdmanae n. sp. Protist 158:209-27.

Hulburt, E. M. 1957. The taxonomy of unarmored Dinophyceae of shallow embayments of Cape Cod, Massachusetts. Biol. Bull. 112:196-219.

Jeffrey, S. W. 1997. Chlorophyll and carotenoid extinction coefficients. In Jeffrey, S. W., Mantoura, R. F. C. \& Wright, S. W. [Eds.] Phytoplankton Pigments in Oceanography: Guidelines to Modern Methods. UNESCO Publishing, Paris, pp. 595-60.

Jeffrey, S. W., Sielicki, M. \& Haxo, F. T. 1975. Chloroplast pigment patterns in dinoflagellates. J. Phycol. 11:374-84.

Kang, N. S., Jeong, H. J., Moestrup, O., Shin, W., Nam, S. W., Park, J. Y., de Salas, M. F., Kim, K. W. \& Noh, J. H. 2010. Description of a new planktonic mixotrophic dinoflagellate Paragymnodinium shiwhaense $\mathrm{n}$. gen., $\mathrm{n}$. sp. from the coastal waters off western Korea: morphology, pigments, and ribosomal DNA gene sequence. J. Eukaryot. Microbiol. 57:121-44.

Kofoid, C. A. \& Swezy, O. 1921. The free-living unarmoured dinoflagellata. Mem. Univ. Calif. 5:1-564.

Larkin, M. A., Blackshields, G., Brown, N. P., Chenna, R., Mcgettigan, P. A., Mcwilliam, H., Valentin, F. et al. 2007. ClustalW2 and ClustalX version 2. Bioinformatics 23:2947-8.

Loeblich III, A. R. \& Smith, V. E. 1968. Chloroplast pigments of the marine dinoflagellate Gyrodinium resplendens. Lipids 3:513.

Moestrup, O., Lindberg, K. \& Daugbjerg, N. 2009a. Studies on woloszynskioid dinoflagellates IV: the genus Biecheleria gen. nov. Phycological Res. 57:203-20.

Moestrup, O., Lindberg, K. \& Daugbjerg, N. 2009b. Studies on woloszynskioid dinoflagellates V. Ultrastructure of Biecheleriopsis gen. nov., with description of Biecheleriopsis adriatica sp. nov. Phycological Res. 57:221-37.

Mooney, B. D., Nichols, P. D., de Salas, M. F. \& Hallegraeff, G. M. 2007. Lipid, fatty acid, and sterol composition of eight species of Kareniaceae (Dinophyta): chemotaxonomy and putative lipid phycotoxins. J. Phycol. 43:101-11.

Murray, S., de Salas, M., Luong-Van, J. \& Hallegraeff, G. 2007. Phylogenetic study of Gymnodinium dorsalisulcum comb. nov from tropical Australian coastal waters (Dinophyceae). Phycological Res. 55:176-84.

Penna, A., Fraga, S., Mase, M., Giacobbe, M. G., Bravo, I., Vila, M., Bertozzini, E., Andreoni, F., Luglie, A. \& Vernesi, C. 2008. Phylogenetic relationships among the Mediterranean Alexandrium (Dinophyceae) species based on sequences of $5.8 \mathrm{~S}$ gene and internal transcript spacers of the rRNA operon. Eur. J. Phycol. 43:163-78.
Penna, A., Vila, M., Fraga, S., Giacobbe, M., Andreoni, F., Riobó, P. \& Vernesi, C. 2005. Characterization of Ostreopsis and Coolia (Dinophyceae) isolates in the western Mediterranean Sea based on morphology, toxicity and internal transcribed spacer 5.8s rDNA sequences. J. Phycol. 41:212-45.

Posada, D. \& Crandall, K. 1998. MODELTEST: testing the model of DNA substitution. Bioinformatics 14:817-8.

Reynolds, E. S. 1963. The use of lead citrate at high $\mathrm{pH}$ as an electron opaque stain in electron microscopy. J. Cell Biol. $17: 208-12$

Riobó, P., Paz, B., Franco, J. M., Vázquez, J. A. \& Murado, M. A. 2008. Proposal for a simple and sensitive haemolytic assay for palytoxin toxicological dynamics, kinetics, ouabain inhibition and thermal stability. Harmful Algae 7:415-29.

Roberts, K. R. \& Taylor, F. J. R. 1995. The flagellar apparatus of Nematodinium armatum. J. Phycol. 31 (Suppl.):21.

Ruiz, J., Antequera, T., Andres, A., Petron, M. \& Muriel, E. 2004. Improvement of a solid phase extraction method for analysis of lipid fractions in muscle foods. Anal. Chim. Acta 520:201-5.

de Salas, M. F., Bolch, C. J. S., Botes, L., Nash, G., Wright, S. W. \& Hallegraeff, G. M. 2003. Takayama gen. nov. (Gymnodiniales, Dinophyceae), a new genus of unarmored dinoflagellates with sigmoid apical grooves, including the description of two new species. J. Phycol. 39:1233-46.

Saunders, G. W., Hill, D. R. A., Sexton, J. P. \& Andersen, R. A. 1997. Small-subunit ribosomal RNA sequences from selected dinoflagellates: testing classical evolutionary hypotheses with molecular systematic methods. Plant Syst. Evol. Suppl. 11:23759.

Scholin, C. A. \& Anderson, D. M. 1994. Identification of groupspecific and strain-specific genetic-markers for globally distributed Alexandrium (Dinophyceae).1. RFLP analysis of SSU ribosomal-RNA genes. J. Phycol. 30:744-54.

Skovgaard, A. 2000. A phagotrophically derivable growth factor in the plastidic dinoflagellate Gyrodinium resplendens (Dinophyceae). J. Phycol. 36:1069-78.

Stamatakis, A., Ludwig, T. \& Meier, H. 2005. RAxMLIII: a fast program for maximum likelihood-based inference of large phylogenetic trees. Bioinformatics 21:456-63.

Steidinger, K., Truby, E. W. \& Dawes, C. J. 1978. Ultrastructure of the red tide dinoflagellate Gymnodinium breve. I. General description. J. Phycol. 14:72-9.

Swofford, D. L. 2002. PAUP*: Phylogenetic Analysis Using Parsimony (* and Other Methods). Version 4.0b10. Sinauer Associates Inc., Sunderland, Massachusetts.

Takayama, H. 1981. Observations on two species of Gymnodinium with scanning electron microscopy. Bull. Plankton Soc. Jpn 28:121-9.

Takayama, H. 1985. Apical grooves of unarmored dinoflagellates. Bull. Plankton Soc. Jpn 32:129-37.

Takayama, H. 1998. Morphological and taxonomical studies on the freeliving unarmored dinoflagellates occurring in the Seto Inland Sea and adjacent waters. $\mathrm{PhD}$ dissertation, University of Tokyo, Tokyo, $211 \mathrm{pp}$.

Takayama, H. \& Adachi, R. 1984. Gymnodinium nagasakiense sp. nov., a red-tide forming dinophyte in the adjacent waters of Japan. Bull. Plankton Soc. Jpn 31:7-14.

Takishita, K., Kawachi, M., Noël, M. H., Matsumoto, T., Kakizoe, N., Watanabe, M. M., Inouye, I., Ishida, K. \& Inagaki, Y. 2008. II Origins of plastids and glyceraldehyde-3-phosphate dehydrogenase genes in the green-colored dinoflagellate Lepidodinium chlorophorum. Gene 410:26-36.

Tengs, T., Dahlberg, O. J., Schalchian-Tabrizi, K., Klaveness, D., Rudi, K., Delwiche, C. F. \& Jakobsen, K. S. 2000. Phylogenetic analyses indicate that the 19' hexanoyloxyfucoxanthin-containing dinoflagellates have tertiary plastids of haptophyte origin. Mol. Biol. Evol. 17:718-29.

Thompson, P. A., Guo, M. X., Harrison, P. J. \& Whyte, J. N. C. 1992. Effects of variation in temperature. II. on the fatty-acid composition of 8 species of marine-phytoplankton. J. Phycol. 28:488-97. 
Watanabe, M. M., Suda, S., Inouye, I., Sawaguchi, T. \& Chihara, M. 1990. Lepidodinium viride gen. et sp. nov. (Gymnodiniales, Dinophyta), a green dinoflagellate with a chlorophyll a and b containing endosymbiont. J. Phycol. 26:741-51.

Wilcox, L. W., Wedemayer, G. J. \& Graham, L. E. 1982. Amphidinium cryophilum sp. nov. (Dinophyceae) a new fresh-water dinoflagellate. II. Ultrastructure. J. Phycol. 18:18-30.

Xu, X.-Q. \& Beardall, J. 1997. Effect of salinity on fatty acid composition of a green microalga from an antarctic hypersaline lake. Phytochemistry 45:655-8.

Xu, Z., Yan, X., Pei, L., Luo, Q. \& Xu, X. 2008. Changes in fatty acids and sterols during batch growth of Pavlova viridis in photobioreactor. J. Appl. Phycol. 20:237-43.

Zapata, M. \& Garrido, J. L. 1991. Influence of injection conditions in reversed-phase high-performance liquid chromatography of chlorophylls and carotenoids. Chromatographia 31: 589-94.

Zapata, M., Rodríguez, F. \& Garrido, J. L. 2000. Separation of chlorophylls and carotenoids from marine phytoplankton: a new HPLC method using a reversed phase C8 column and pyridine-containing mobile phases. Mar. Ecol. Prog. Ser. 195:2945 .

Zhu, C., Lee, Y. \& Chao, T. 1997. Effects of temperature and growth phase on lipid and biochemical composition of Isochrysis galbana TK1. J. Appl. Phycol. 9:451-7.

\section{Supplementary Material}

The following supplementary material is available for this article:

Table S1. European Molecular Biology Laboratory (EMBL) accession numbers and sample locations of the different strains used in internal transcribed spacer (ITS) sequence studies.

Table S2. European Molecular Biology Laboratory (EMBL) accession numbers and sample locations of the different strains used in LSU sequence studies.

Please note: Wiley-Blackwell are not responsible for the content or functionality of any supporting materials supplied by the authors. Any queries (other than missing material) should be directed to the corresponding author of the article. 


\section{Author Query Form}

Journal: JPY

Article: $\quad$ 968-10-049

Dear Author,

During the copy-editing of your paper, the following queries arose. Please respond to these by marking up your proofs with the necessary changes/additions. Please write your answers on the query sheet if there is insufficient space on the page proofs. Please write clearly and follow the conventions shown on the attached corrections sheet. If returning the proof by fax do not write too close to the paper's edge. Please remember that illegible mark-ups may delay publication.

Many thanks for your assistance.

\begin{tabular}{|c|c|c|}
\hline Query reference & Query & Remarks \\
\hline Q1 & $\begin{array}{l}\text { AUTHOR: } 4^{\prime}, 6 \text {-diamidino-2-phenylindole. Is this the correct defi- } \\
\text { nition for DAPI? Please change if this is incorrect. }\end{array}$ & \\
\hline Q2 & $\begin{array}{l}\text { AUTHOR: Please provide manufacturer details for 'ProgRes } \\
\text { capturePro v 2.1sofware' (if applicable.) }\end{array}$ & \\
\hline Q3 & $\begin{array}{l}\text { AUTHOR: AOAC } 1990 \text { has been changed to Association of Offi- } \\
\text { cial Analytical Chemists (AOAC) } 1990 \text { so that this citation } \\
\text { matches the Reference List. Please confirm that this is correct. }\end{array}$ & \\
\hline $\mathrm{Q}^{4}$ & $\begin{array}{l}\text { AUTHOR: Fuentes-Grünewald et al. }(2009) \text { has been changed to } \\
\text { Fuentes-Grunewald et al. }(2009) \text { so that this citation matches the } \\
\text { Reference List. Please confirm that this is correct. }\end{array}$ & \\
\hline Q5 & $\begin{array}{l}\text { AUTHOR: Gómez et al. } 2009 \text { b has been changed to Gomez et al. } \\
2009 b \text { so that this citation matches the Reference List. Please } \\
\text { confirm that this is correct. }\end{array}$ & \\
\hline Q6 & $\begin{array}{l}\text { AUTHOR: Gómez et al. 2009a has been changed to Gomez et al. } \\
\text { 2009a so that this citation matches the Reference List. Please con- } \\
\text { firm that this is correct. }\end{array}$ & \\
\hline Q7 & $\begin{array}{l}\text { AUTHOR: Gómez et al.2009b has been changed to Gomez et al. } \\
2009 \text { b so that this citation matches the Reference List. Please } \\
\text { confirm that this is correct. }\end{array}$ & \\
\hline Q8 & $\begin{array}{l}\text { AUTHOR: Loeblich III and Smith } 1968 \text { has been changed to Lo- } \\
\text { eblich and Smith } 1968 \text { so that this citation matches the Reference } \\
\text { List. Please confirm that this is correct. }\end{array}$ & \\
\hline Q9 & $\begin{array}{l}\text { AUTHOR: Mainly due... the genus Barrufeta. In this sentence } \\
\text { 'probable' has been reworded 'probability' for clarity. Please } \\
\text { check and confirm it is correct. }\end{array}$ & \\
\hline Q10 & $\begin{array}{l}\text { AUTHOR: Please check and provide all author names for the ref- } \\
\text { erence 'Penna et al. 2008' }\end{array}$ & \\
\hline Q11 & $\begin{array}{l}\text { AUTHOR: Please check and provide all author names for the ref- } \\
\text { erence 'Takishita et al. 2008' }\end{array}$ & \\
\hline
\end{tabular}



are made in text also. Please check. 


\section{Proof Correction Marks}

Please correct and return your proofs using the proof correction marks below. For a more detailed look at using these marks please reference the most recent edition of The Chicago Manual of Style and visit them on the Web at: http://www.chicagomanualofstyle.org/home. html

\begin{tabular}{|c|c|c|}
\hline Instruction to typesetter & Textual mark & Marginal mark \\
\hline Leave unchanged & ... under matter to remain & (stet) \\
\hline $\begin{array}{l}\text { Insert in text the matter } \\
\text { indicated in the margin }\end{array}$ & $\wedge$ & $\begin{array}{l}\wedge \text { followed by new } \\
\text { matter }\end{array}$ \\
\hline Delete & $\begin{array}{l}\sigma_{\text {through single character, rule or underline }} \\
\text { or }\end{array}$ & matter \\
\hline $\begin{array}{l}\text { Substitute character or } \\
\text { substitute part of one or } \\
\text { more word(s) }\end{array}$ & $\begin{array}{l}\sigma \text { through all characters to be deleted } \\
K \text { through letter or } \\
\longrightarrow \text { through characters }\end{array}$ & $\begin{array}{l}\text { new character } \lambda \text { or } \\
\text { new characters } \lambda\end{array}$ \\
\hline Change to italics & — under matter to be changed & ital \\
\hline Change to capitals & $\equiv$ under matter to be changed & (caps \\
\hline Change to small capitals & $=$ under matter to be changed & (sc) \\
\hline Change to bold type & $\sim$ under matter to be changed & (bf) \\
\hline Change to bold italic & $\bar{\sim}$ under matter to be changed & bf+ital \\
\hline Change to lower case & B & (2) \\
\hline Insert superscript & $\checkmark$ & $\begin{array}{l}\checkmark \text { under character } \\
\text { e.g. } v\end{array}$ \\
\hline Insert subscript & $\wedge$ & $\begin{array}{l}\wedge \text { over character } \\
\text { e.g. } \hat{\Sigma}\end{array}$ \\
\hline Insert full stop & $\odot$ & $\odot$ \\
\hline Insert comma & $\hat{\jmath}$ & $\hat{\jmath}$ \\
\hline Insert single quotation marks & $\sqrt{2}$ & $\sqrt{2}$ \\
\hline Insert double quotation marks & $\ddot{*}$ & $\ddot{w}$ \\
\hline Insert hyphen & $=$ & $=$ \\
\hline Start new paragraph & 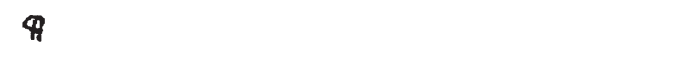 & $\Phi$ \\
\hline Transpose & $\sqcup$ & $\sqcup$ \\
\hline Close up & linking $\bigcirc$ characters & 2 \\
\hline $\begin{array}{l}\text { Insert or substitute space } \\
\text { between characters or words }\end{array}$ & $\#$ & \# \\
\hline $\begin{array}{l}\text { Reduce space between } \\
\text { characters or words }\end{array}$ & J & こ \\
\hline
\end{tabular}

